\title{
Leda y el cisne en la musivaria romana
}

\author{
M. ${ }^{a}$ Pilar San Nicolás Pedraz
}

\begin{abstract}
RESUMEN ABSTRACT
Análisis iconográfico de los mosaicos IConographical analysis of the roman romanos de Leda y el cisne en sus mosaics of Leda and the swan in distintas fases del mito, narradas por las fuentes literarias -el encuentro de different phases of the myth, narrated by the literary sources - the meeting

Leda y Júpiter, metaniorfoseado en cisne, la hierogamia, el huevo de Helena y los Dióscuros-, con especial atención a aquellos ejemplares que muestran particularidades artísticas y alergóricas dentro del repertorio. between Leda and Jupiter, transformed in swan, the hierogamia, the egg of Helena and the Dioscuros - with special attention to those examples that show artistic and allegoric peculiarities in the repertory.
\end{abstract}

Leda, nombre que parece derivar del epíteto licio lada, que significa "mujer» ", fue mencionada numerosas veces en los textos antiguos como hija del rey de Etolia, Testio y de Eurítemis (Apol. Bibl. 1 7, 10), hermana de Altea e Hipermestra (Hes. Frag. 23a, 3-5), esposa de Tindareo, rey de Esparta (Ov. Met. VI 109), y madre de grandes personajes mitológicos, Timandra, esposa de Equemo, Filonoe, a la que Artemis hizo inmortal (Apol. Bibl. III 10, 5), Clitemnestra, esposa de Agamenón (Hes. Frag. 23a, 7-10; Apol. Bibl. III 10, 6), Febe (Eur. Iph. in Aulide 49-51), Helena, la más bella entre las mortales (Hom. II. III, 426; Od. IV 184), y los Dióscuros, Pólux y Cástor, que según Homero (h.17 y 33) son, al igual que Helena,

1 H. GeISAU, «Leda», KIPauly III, 1976, 532. 
hijos de Zeus, mientras que Píndaro (Nem. X 78-82) y Apolodoro (Bibl. $10,7)$ consideran a Cástor hijo de Tindareo y a Pólux de Zeus.

La leyenda de la unión de Leda con Zeus, que sustituye a la anterior hierogamia de Némesis ${ }^{2}$ y que gozó de una gran aceptación en el arte helenístico-romano, fue inmortalizada por Eurípides, siglo $V$ a.C., en varias de sus obras (Hel. 16-22; Iph. in Aulide 794-800; Or. 1385-1387) y posteriormente por otros mitógrafos (Isokr. X, 59; Anth. Pal. V, 307).

Según el relato mitológico, un día, cuando Leda se bañaba en un estanque, se le acercó un cisne de resplandeciente blancura, metamorfosis que había adoptado Zeus para seducir a la joven sin despertar sospechas. Esa misma noche la princesa etolia se unió a su esposo, y a su tiempo nacieron Pólux y Helena, Cástor y Clitemnestra.

La musivaria romana ha proporcionado varios ejemplos del mito que se pueden dividir en tres grandes grupos. Una serie con la primera fase de la leyenda que sería el encuentro de Leda y Júpiter metamorfoseado en cisne, otra en las que se representa abiertamente el momento de la unión, y una tercera serie con la representación del huevo de Helena. La cronología de estos ejemplares abarca desde mediados del siglo II al VI.

Del primer episodio de la leyenda o el encuentro de ambos personajes, existen diferentes versiones iconográficas y en ninguna de ellas se muestra al águila que persigue al cisne, cuya narración más conocida se encuentra en el prólogo de la obra de Eurípides, Helena (17), donde la misma protagonista dice "...es fama que Zeus, transformado en cisne, llegó volando hasta mi madre Leda, fingiendo huir de la persecución de un águila... ${ }^{3}$. El momento mismo de la llegada del cisne solo está re-

\footnotetext{
2 La primera y más importante versión mítica de Némesis se encuentra en los Cypria de Estásino (Athen. VII 334B), según la cual Némesis perseguida por Zeus huye y se metamorfosea (pez, liebre, abeja, ratón y oca), pero por fin es alcanzada y fecundada por el dios, que para ello, en la Némesis de Cratino, toma la forma de un cisne, a su debido tiempo pone un huevo, del que llevado a Leda (ya sea porque lo encontró la propia Leda, o se lo llevó un pastor, o Hermes o, incluso, cayó del cielo o de la luna según las distintas versiones), nacerá Helena. Todo ello, según Eratóstenes (Cat. 25), ocurrió en Ramnunte, donde se erigió un templo a Némesis; este mismo autor señala que el cisne fue convertido posteriormente en constelación. Pausanias (Descr. Grec. I $33,2-4$ ) confirma igualmente el templo de Némesis en Ramnunte, en donde existía una estatua de la diosa realizada por Fidias con mármol de Paros.

3 La presencia del águila, que indicaría los preliminares del mito, aunque no es muy frecuente en el arte antiguo, se documenta en una copa etrusca de figuras rojas del siglo IV a. C. procedente de Clusium (Chiusi) y en la pintura pompeyana de la Casa del Citarista de la época de Augusto, J. ChamAY, "Leda, le cygne et ... l'angle", Antike Kunst 26, 1983, 44-47, lám. 14; LIMC VI Leda (in Etruria), 1992, n. ${ }^{\circ}$; LIMC VI, Leda, 1992, n. ${ }^{\circ} 61$; C. AlCALDE MARTín, «El mito de Leda: sus metamorfosis en la Historia del Arte», en J.L. CaLvo MARtínez (ed.), Religión, magia y mitología en la antigüedad clásica, Granada 1998, 13. Para las descripciones e ilustraciones de estos ejemplares, cf. en este artículo las figuras 15 y 16 . Una versión literaria indica que el águila
} 
presentado en un fragmento del mosaico de Lambaesis, del siglo III, conservado en el Museo de Tazoult ${ }^{4}$. Leda aparece de frente, en pie, desnuda y levanta el brazo izquierdo hacia el cisne que desciende hacia ella. A su derecha está representado Eurotas (Fig. 1), sentado en una roca y apoyando su codo izquierdo en una urna de la que mana agua, iconografía propia de los ríos ${ }^{5}$, aludiendo que en sus orillas tuvo lugar la seducción de la princesa etolia, tal como lo narra Antifilio ( $P a l$. $\vee 307$ ), lugar frecuentado por los cisnes (Eurip. Hel. 1487-1492). A su izquierda figura Eros sosteniendo una antorcha, símbolo de la pasión amorosa de Zeus por Leda. Como ambiente terrestre, la escena tiene un fondo verde con rosas.

Los paralelos más próximos para la secuencia de este ejemplar se documentan en un fragmento de askos del Museo de La Canea, de ca. 400 a.C., en una terracota de Baghdad, de época helenística y en el sarcófago de Aix-en-Provence, de la segunda mitad del siglo II, que se conserva en el Museo de Granet, en los cuales, con algunas variantes, se muestra a Leda sentada o en pie tendiendo sus brazos al cisne que se aproxima hacia ella ${ }^{6}$.

Un segundo momento dentro de esta fase, que es el más representado en la musivaria romana, muestra a Leda con el cisne, en el que la actitud de la joven ofrece algunas variantes iconográficas. En una de ellas acaricia al cisne que aparece sumiso a su lado, con objeto de conseguir la confianza de Leda, que en algunos ejemplares tal vez ya lo ha conseguido; en otros casos la joven, conocedora de las intenciones del animal se asusta, e inicia un gesto de huida, levantando la mano o volviéndose esquivamente de su lado, mientras que el cisne sostiene un extremo del manto de la joven con intención de retenerla. En todos los casos Leda se encuentra en pie, semidesnuda, con manto o himation por detrás de la espalda, que en ocasiones aparece arqueado o flotando utilizándose para figurar este momento inicial del proceso amoroso de ambos personajes un ambiente terrestre, a veces próximo a un río, mediante pilastras, árboles, rosas, plantas acuáticas o la presencia de

era Afrodita, metamorfosis que había empleado para ayudar al dios, cf. A. GARCIA MASEGOSA, LOS amores humanos de Zeus, Vigo 1998, 112.

4 F.G. Panchtere, Inventaire des mosaïques de la Gaule et de l'Afrique, III, Afrique Proconsulaire, Numidie, Maurétanie (Algérie), Paris 1911 n. ${ }^{\circ}$ 183; K.M.D. DunBaBIN, The mosaics of Roman Nort Africa, Oxford 1978, 263.

5 M.P. San Nicolás Pedraz, «Representaciones alegóricas de fuentes y rios en los mosaicos romanos de Hispania», en M. J. Peréx Agorreta (Ed.), Termalismo Antiguo, (I Congreso Peninsular; Arnedillo, La Rioja 1996), UNED-CV, Madrid 1997, 467-479.

6 LIMC IV, Helena, 1988, n. ${ }^{\circ} 11$; LIMC VI, Leda, 1992, n. ${ }^{\circ} 1,2$ y 141. 


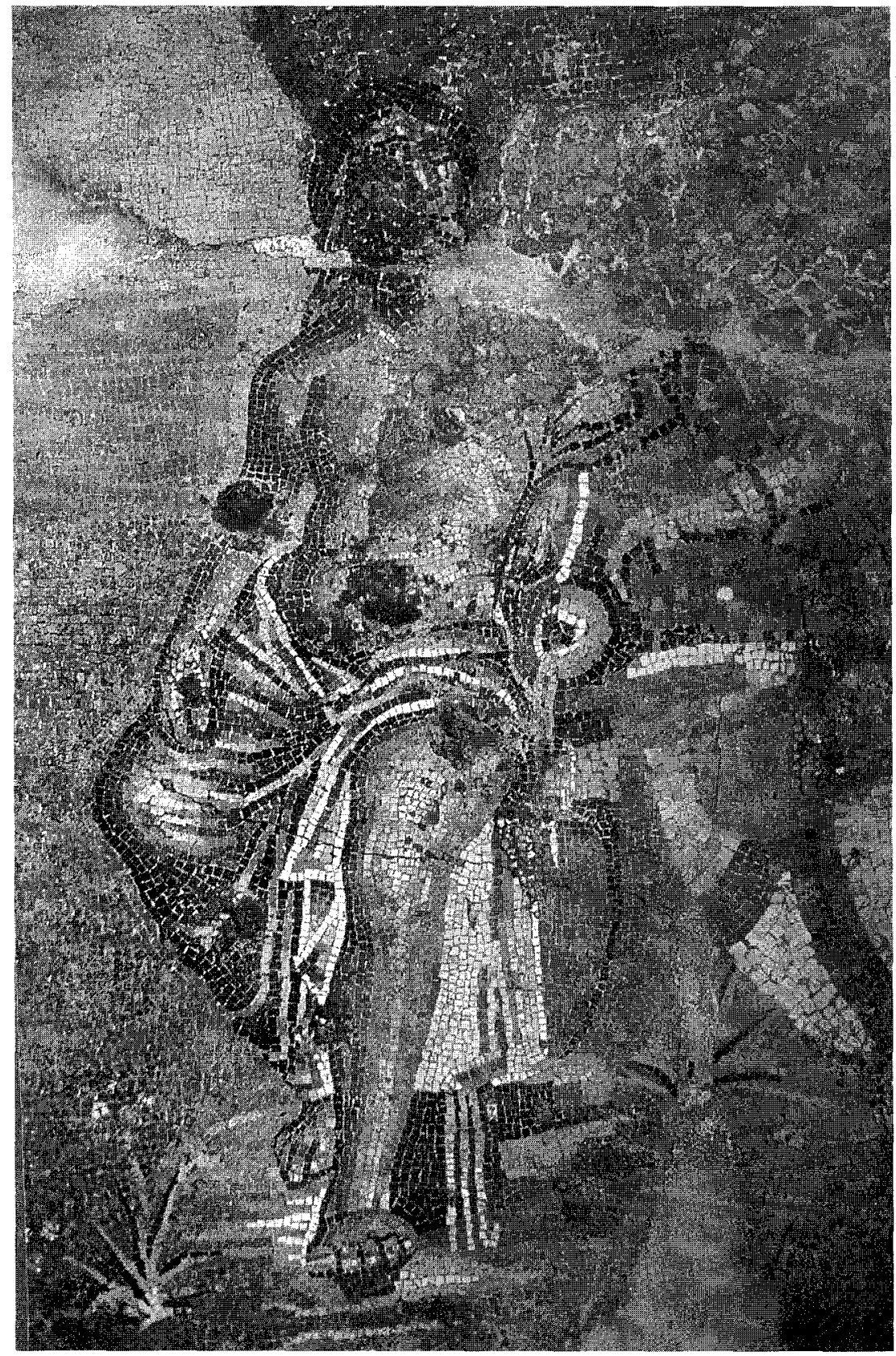

Fig. 1. Río Eurotas. Detalle del mosaico de Lambaesis. Museo de Tazoult. 
Eurotas. Solo en una ocasión esta secuencia se efectúa ante las mujeres de Esparta, como evidencia el mosaico de Nea Paphos. Otros recursos utilizados para representar este momento inicial son, al igual que en el pavimento de Lambaesis, la presencia de la figura de Eros y la representación del cisne con las alas explayadas o levantadas, en actitud de movimiento, cuyas proporciones son, generalmente, naturales, que se convertirá del mismo tamaño que Leda en la mayoría de los ejemplares de la segunda fase con el momento de la unión de la pareja.

El mosaico de la ciudad chipriota de Nea Paphos, fechado a finales del siglo II, decoraba la sala de recepción de la Casa de Aión y se conserva in situ. La superficie del pavimento de forma cuadrada, está compuesta por cinco cuadros, distribuidos en tres paneles superpuestos, midiendo el central el doble que los otros, con variadas escenas en las que intervienen numerosos personajes mitológicos, tres de ellas de carácter báquico: la infancia de Diónisos, Casiopea y las Nereidas, Triunfo de Diónisos, Juicio de Apolo contra Marsyas ${ }^{7}$. El cuadro que muestra a Leda y a las mujeres de Esparta y, por consiguiente, ilustra el primer momento del encuentro, cuando Júpiter transformado en blanco cisne ya está en Lacedemonia, ocupa el primer tema mitológico del pavimento ${ }^{8}$ (Fig. 2). Leda aparece en el centro, desnuda y adornada con diadema, collar y brazaletes; tiene los pies dentro del agua, haciendo alusión a que el encuentro se produjo cuando se bañaba, como relatan los mitógrafos. Lleva el himation por detrás de la espalda y es sostenido con la mano izquierda, mientras que tiende la mano derecha hacia el cisne, el cual agarra con su pico un extremo del manto. Todos los personajes están identificados por su nombre en griego, destacando en la derecha las representaciones de Eurotas, semejante al del mosaico de Lambaesis, y Lacedemonia como personificaciones del lugar geográfico en donde tiene lugar la escena; en la izquierda aparece un sátiro y un altar haciendo alusión al carácter báquico del programa iconográfico del conjunto ${ }^{9}$, como ocurre con otras representaciones de los Amores de Zeus ${ }^{10}$.

\footnotetext{
7 W.A. DASZEWSKI y D. MICHAELIDES, Guide des mosaïques de Paphos, Chipre 1989, 63-71, figs. 45-51; J.M. BLAZZUEZ et alii, "Consideraciones en torno a los mosaicos romanos de Chipre», Lvcentvm XIV-XVI, 1995-1997, 73-77, figs. 25-32.

8 Tindareo, expulsado de Lacedemonia por Hipocoonte y sus hijos, se refugió en Etolia donde conoció a Leda, posteriormente cuando Heracies le repuso en el trono, Leda acompañó a su esposo a Lacedemonia.

9 M.E. OLSZEWSKI, «L allégorie, les mystères dionisiaques et la mosaïque de la maison d'Aiôn de Nea Paphos à Chypre», BullAIEMA 13, 1990-1991, 444-463.

to En particular el mito de Europa, cf. G. López Monteagudo y M.P. San Nicolás Pedraz, «E mito de Europa en los mosaicos hispano-romanos. Análisis iconográfico e interpretativo", Espacio, Tiempo y Forma, II, 18, 1995, 423
} 


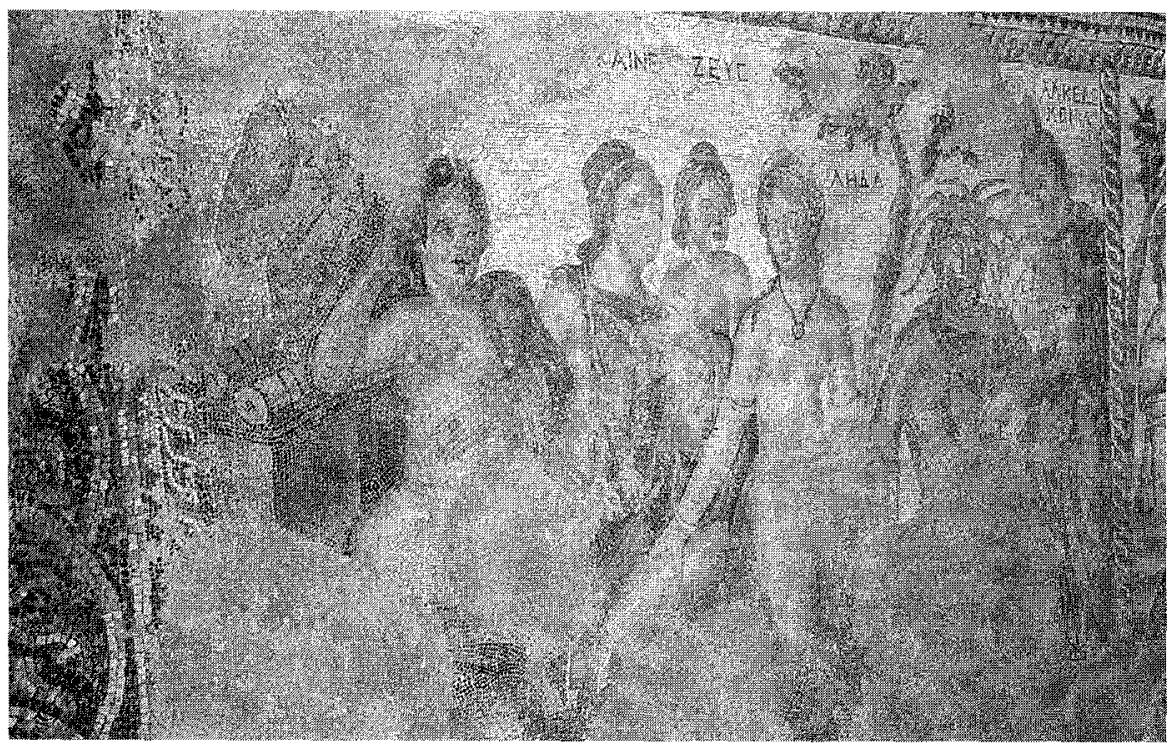

Fig. 2. Mosaico de Nea Paphos. Casa de Aión. In situ. Foto G. López Monteagudo.

La composición de Leda junto a sus compañeras aparece también documentada en un interesante relieve copto de Egipto, que se conserva en Ashmolean Museum (Oxford), de finales del siglo IV o principios del $V$. En los extremos, encuadrando la escena del encuentro, se han figurado dos jóvenes, vistas de frente y desnudas, así como el río Eurotas, situado a la izquierda de Leda, la cual aparece de espaldas, iconografía que coincide con la de los pavimentos de Kouklia-Palaepaphos (Chipre), Suasa (Italia) y Ecija (España) ofreciendo otras secuencias del tema (infra).

El mosaico de la habitación 13 de la Casa de Menandro en Antioquía, que se fecha en época severiana, forma un rectángulo, dividido en cuatro secciones radiales separadas por palmeras, a partir de un águila central. En las secciones se han representado Eros y Psique, lo y Argos o Paris Oenone, Apolo y Dafne, Leda y el cisne ${ }^{11}$. En la última escena, conservada en el Museo de Arte de la Universidad de Princeton, aparece la princesa desnuda y con la mano derecha sostiene el himation que cae sobre su espalda. La figura, aunque muy deteriorada, parece que avanza hacia

11 D. LEVI, Antioch Mosaics Pavements, Princeton 1947, 208-209, lám. 46 a. 
el cisne, de grandes dimensiones, que se encuentra en su lado derecho, de frente, con las alas desplegadas y volviendo la cabeza hacia ella para cogerla un extremo del manto. La escena presenta un paisaje con vegetación acuática; en la parte derecha, detrás de Leda, se ha representado, al igual que en el pavimento de Lambaesis, la figura de Eros, el cual sostiene una antorcha en la mano izquierda mientras que con la derecha señala al grupo, proporcionando a esta fase inicial el contenido erótico que va a caracterizar al resto del relato mítico (Fig. 3).

Este momento del encuentro, en donde tiene lugar la actitud cariñosa de la princesa y la apariencia inofensiva del ave, también se ha figurado en el mosaico hallado en la Casa K de la Explanada de Lices, en Arlès, que se conserva in situ, fechado en el siglo $\mathrm{II}^{12}$, siendo por tanto el ejemplar musivo más antiguo del tema mitológico. Leda aparece vista de frente, mirando ligeramente a su derecha y tendiendo su mano para acariciar el ave que se encuentra a su lado, con las alas levantadas; está desnuda y el velo flota detrás de la espalda sin arquease (Fig. 4).

El mismo tipo se vuelve a encontrar en el ejemplar de Baccano, datado en el siglo IV ${ }^{13}$, en donde se manifiesta mejor la inclinación de Leda para acariciar al cisne en actitud confiada. La joven aparece desnuda y a su lado derecho el cisne con las alas explayadas; lleva el manto arqueado detrás de la espalda, como en las pinturas de la Villa de Campo Varano de Stabies y de Herculano, ambas conservadas en el Museo Nacional de Nápoles ${ }^{14}$, aunque sin llegar a convertirse en una figura velificante sua manu. Junto a ellos se han representado un árbol y una columna haciendo someramente alusión al lugar terrestre en el que se desarrolló la escena (Fig. 5). Este mosaico que se conserva en el Museo Nazionale de Roma, ostenta una composición rectangular compuesta de varios cuadros con diversos temas mitológicos, entre los que se encuentra, en la esquina superior izquierda, Ganímedes y el águila ${ }^{15}$. El grupo

12 F. SALVIAT, «Informations Archéologiques. Circonscription de Provence», Gallia 35, 1977, 515-517, figs. 7-8; M. GAUTHIER, «Informations Archéologiques. Circonscription de Provence AlpesCôte-d'Arur», Gallia 44, 1986, 391; C. BALMELle, "Recueil des Mosaïques de la Gaule et recherches en cours", MGR IV, 1994, 326, lám. CCXV, 1.

13 G. BECATTI et alii, Mosaici Antichi in Italia. Regione Settima. Baccano: Villa Romana, Roma 1970, 25-28, n. ${ }^{\circ}$ 10, lám. X.

14 LIMC VI, Leda, 1992, n. ${ }^{\circ} 66$ y 77.

15 G. BECATTl et alii, op. cit (nota 13), 22-25, lám. IX. En algunos sarcófagos coinciden la representación del mito de Leda con el de Ganímedes a los que se les ha dado un sentido escatológico que algunos autores justifican como el deseo de unirse a la divinidad tras la muerte; sobre estos sarcófagos y posibles significados cf. H. SICHTERMANN, "Leda und Ganymed", MarbWPr 1984 (Symposium über die antiken Sarkophage, Pisa 1982), 43-57; H. WIEGARTZ, «Leda und der Kaiserzeitlichen attischen Plastik», Boreas 6, 1983, 168-196. 


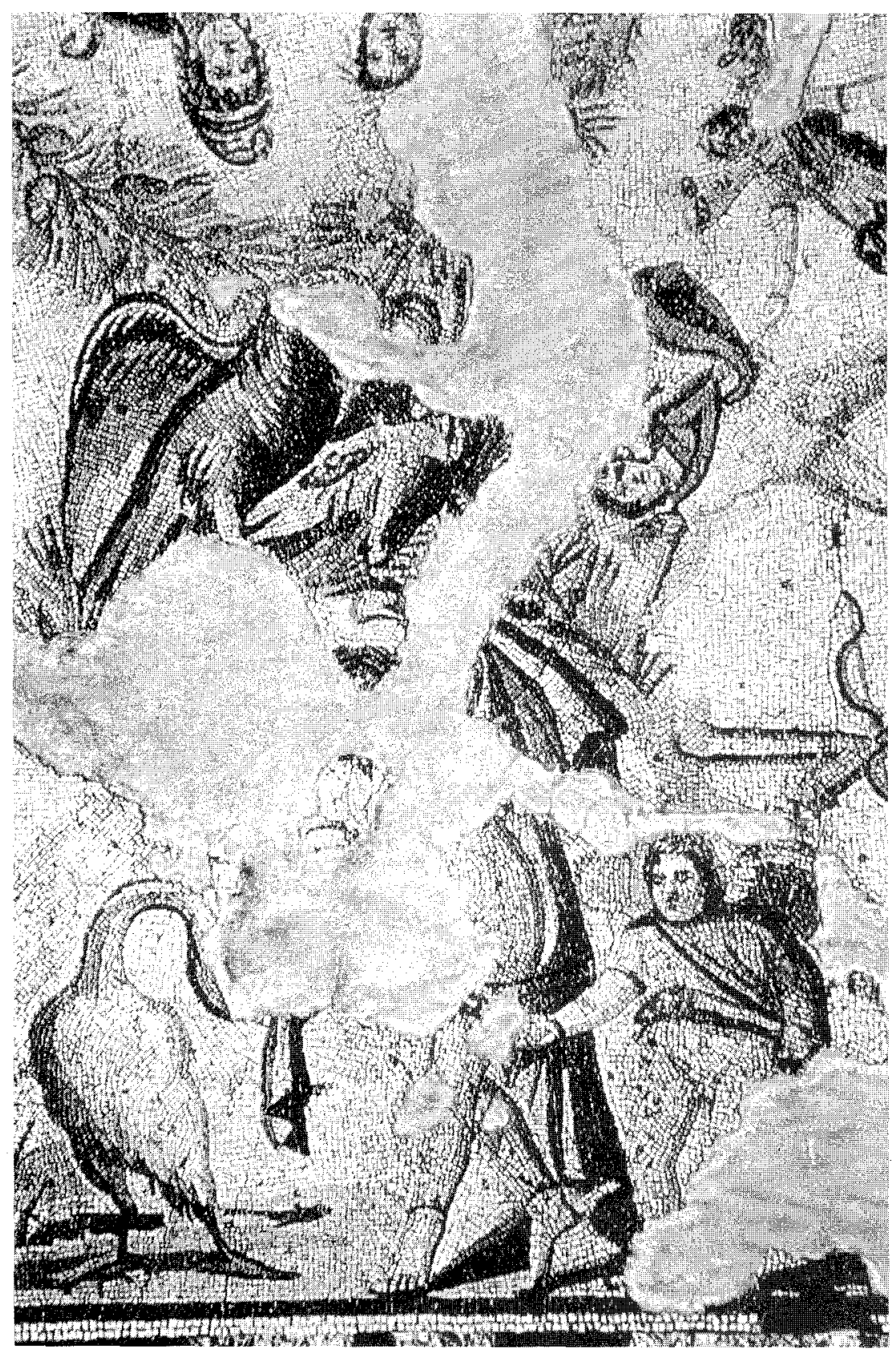

Fig. 3. Mosaico de Antioquía. Casa de Menandro. 


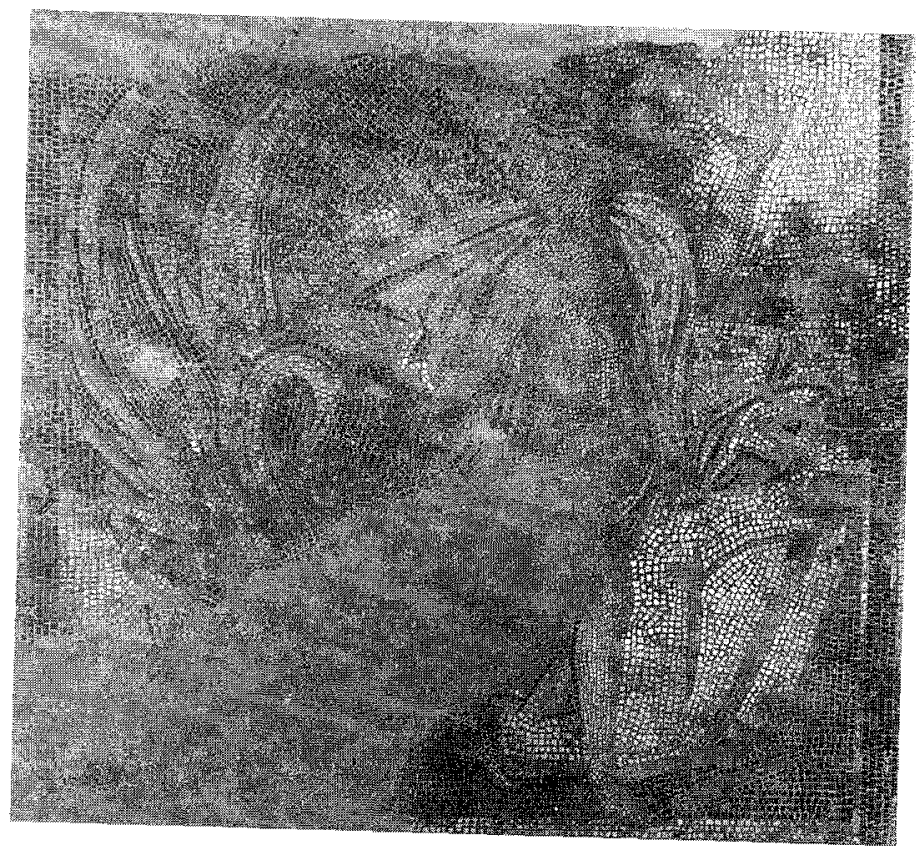

Fig. 4. Mosaico de Arlès. In situ.

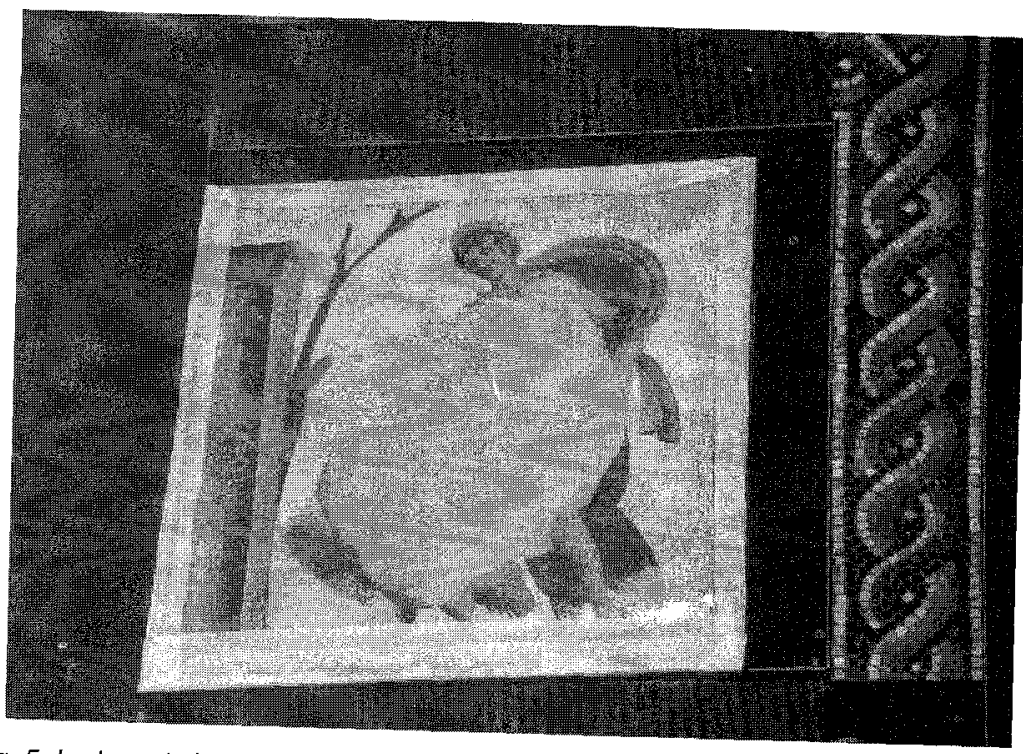

Fig. 5. Leda y el cisne. Mosaico de Baccano. Museo Nacional de Roma. Foto G. López Monteagudo. 
de Leda y el cisne ocupa la otra esquina superior derecha, y en otro compartimento, situado al lado, está representado Eurotas recostado hacia la izquierda, portando en su mano derecha el cuerno de la abundancia como símbolo de fecundidad, y en la izquierda lleva, al igual que en el mosaico de Lambaesis, una rama ${ }^{16}$ (Fig. 6). Precisamente, en este procedimiento de descomponer la escena presentándola en paneles o cuadros diferentes, pero próximos, radica la originalidad de este pavimento itálico frente a las otras representaciones del Imperio.

La misma escena se observa en otros emblemas musivos, como el de Tiro, datados en el siglo III ${ }^{17}$, donde Leda tiene su mano izquierda sobre el cuello del cisne mientras se agarra con la mano derecha un extremo del manto que cae.

En el mosaico de Beyrouth, de ca. 300, la escena de Leda y el cisne se representó junto con otros amores de Júpiter: sátiro y Antiope, Dánae y la lluvia de oro, Ganímedes y el águila ${ }^{18}$. En la parte superior izquierda se ha figurado a la princesa, desnuda y de frente, llevando un manto por detrás de la espalda que alza con la mano izquierda, mientras que con la derecha acaricia al ave; éste, de grandes dimensiones y con las alas desplegadas, vuelve su cabeza hacia ella para agarrarle el manto. (Fig. 7).

Esta representación tiene un enorme interés iconográfico, ya que el tipo de Leda levantando la mano a la vez que sostiene el manto es propio de la conocida obra del escultor Timoteo, de mediados del siglo IV a.C., de las que existen numerosas copias de época helenística y romana, cuyo mejor exponente es la conservada en el Museo Capitolino de Roma, evocando la primera fase del mito, en donde siguiendo la versión de Eurípides, la joven protege al cisne amenazado por el águila (Fig. 8). No obstante, el tipo se documenta ya desde el siglo $\mathrm{V}$ a. C., como demuestran la escultura griega de mármol de Boston, con la particularidad de que el grupo es menos erótico, y las numerosas terracotas, especialmente beocianas, fechadas a finales del V-III a. C., que podrían derivar de un antecedente de la escultura de Timoteo ${ }^{19}$.

16 G. BecatTi et alii, op. cit. (nota 13), 35-36, lám. XIV; M.R. SANZI DI Mino, «ll mosaico con cassettonato policromo dalla villa romana di Baccano". Atti del III Colloquio AISCOM, 1996, 501514.

17 M. CHEHAB, “Mosaïques inédites du Liban», MGR II, 1975, 373.

18 M. CHEHAB, «Mosaïques du Liban», BullMusBeyrouth 14-15, 1958-1959, 21-26, láms. VIII y $X, 2$.

19 A. RiECHE, «Die kopien der Leda des Timotheos», APL XVII, 1978, 21-50, láms 10-34; LIMC VI, Leda, 1992, 245, n. ${ }^{\circ} 5-14,73-74$. 


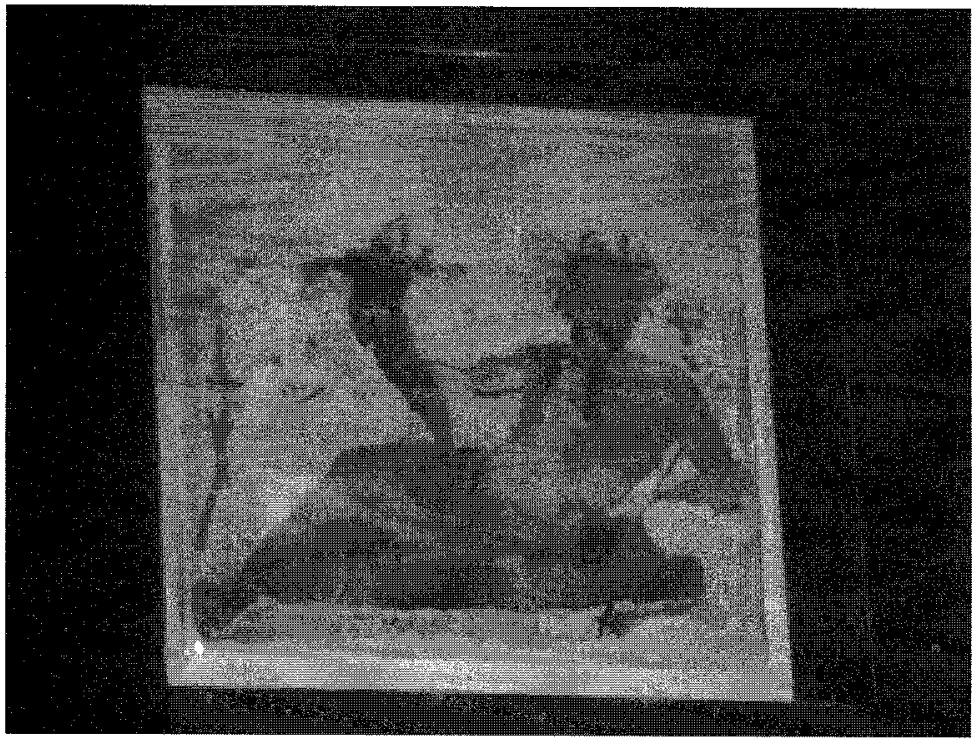

Fig. 6. Río Eurotas. Mosaico de Baccano. Museo Nacional de Roma. Foto G. López Monteagudo.

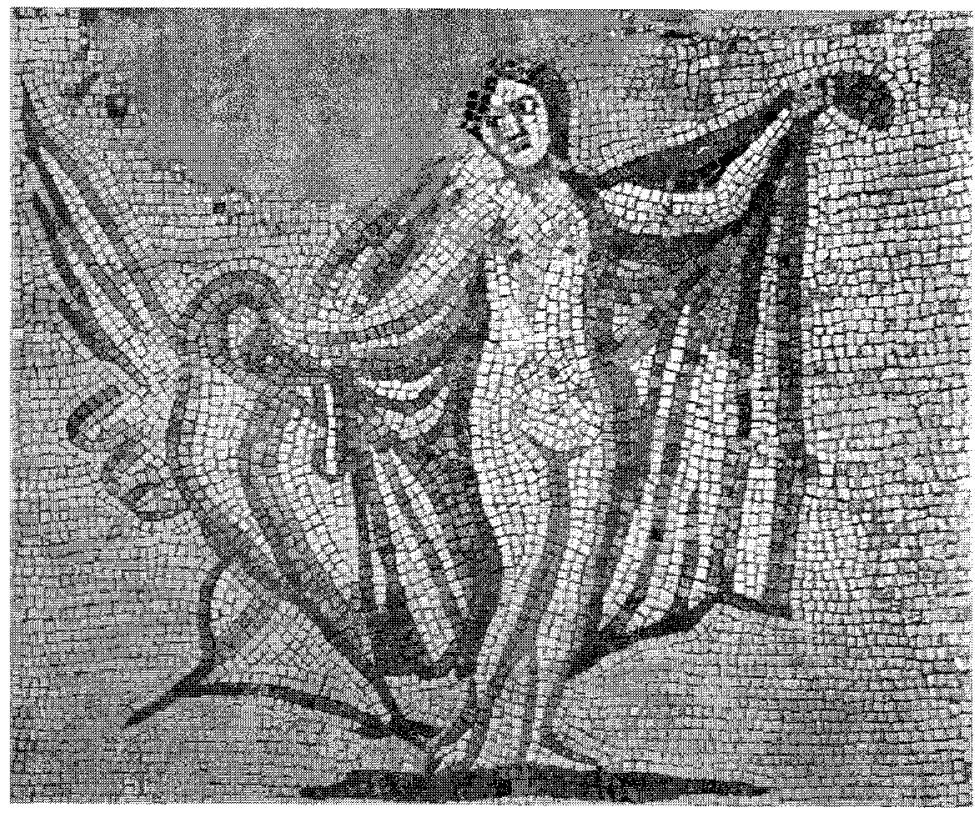

Fig. 7. Mosaico de Beyrouth. 


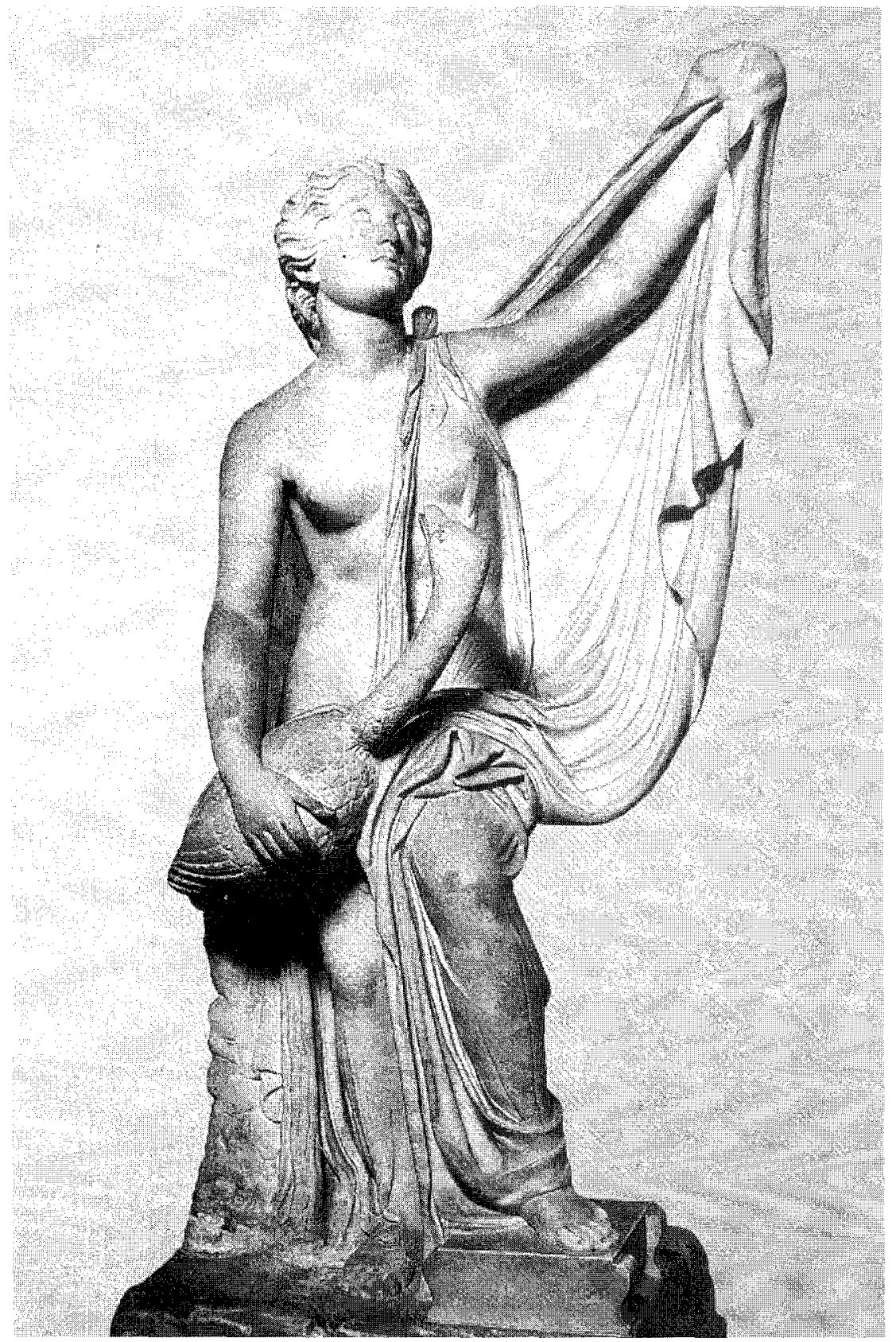

Fig. 8. Escultura de Leda y el cisne. Villa Borghese, Roma. 
En el panel procedente de Salamis, del que solo se conserva la mitad izquierda, se ha representado también el encuentro de la princesa y el cisne (Fig. 9). Aparece el río Eurotas identificado por su nombre en griego, recostado al igual que en el citado pavimento de Baccano, pero en posición invertida, apoyando su codo derecho en una urna de la que mana agua como en el de Lambaesis. A su derecha se aprecia un ala y el cuello del cisne, así como parte de la figura de un eros volando encima de ellos, con el brazo extendido hacia la izquierda, señalando al grupo como en el ejemplar de Antioquía. Probablemente Leda estaría representada en la parte derecha del mosaico. Se fecha en la primera mitad del siglo III ${ }^{20}$.

También muy deteriorada se encuentra la escena del pavimento de Ouled Agla, de comienzos del siglo IV, conservado en el Museo de Argel ${ }^{21}$. En el recuadro rectangular que preside el emblema, el episodio de Leda y el cisne figura junto con otros amores de Júpiter: Dánae recibiendo la lluvia de oro, sátiro y Antiope, Ganímedes dando de beber al águila en presencia de Júpiter, Europa y el toro, coincidiendo en esta conjunción con los mosaicos citados de Beyrouth y Palermo. Leda está representada en el extremo izquierdo y de ella únicamente se conserva la cabeza y una parte del cuerpo; el cisne estaría figurado a su izquierda como parece indicar la inclinación del rostro de la joven (Fig. 10).

El mosaico de Nîmes, datado a mediados del siglo III ${ }^{22}$, presenta a Leda, vista de frente, con el manto flotando sobre la espalda y cubriendo las piernas, mientras que el ave se aproxima hacia ella con las alas levantadas. A la izquierda está representada una alta columna con un vaso en su cima, determinando el lugar de la escena como un santuario al igual que en la pintura pompeyana de la Casa del Citarista (infra) (Fig.11). Las particularidades más sobresalientes de esta representación son la posición de los brazos levantados de la joven, en actitud de asombro, y la expresión desconcertada de su rostro que parecen indicar que ya es conocedora de las intenciones del cisne, constituyendo por consiguiente un momento de transición entre las representaciones anteriores y el grupo siguiente, en el cual se aparta del animal.

20 V. Karageorghis, Salamis in Cyprus, 1969, 161, lám. 17; D. Michaelides, Cypriot Mosaics, 1987, 27-28, n. 26, lám 12; J. BALTY, RDAC 1988/2, 214-216, láms. 67, 1 y 68, 1.

21 I. LAVIN, "Antioch, hunting mosaics and their sources Dumbarton Oaks", Papers 17, 1963, 264, fig. 131.

22 A. NICKELS, G. BARRUOL, "Informations Archéologiques. Circonscription de LanguedocRoussillon", Gallia 41, 1983, 515; D. DARDE et alii, Dossiers Histoire et archéologie 99, 1985, 50 con fig.; C. BALMELLE, op. cit. (nota 12), 325-326, lám. CCXIV. 


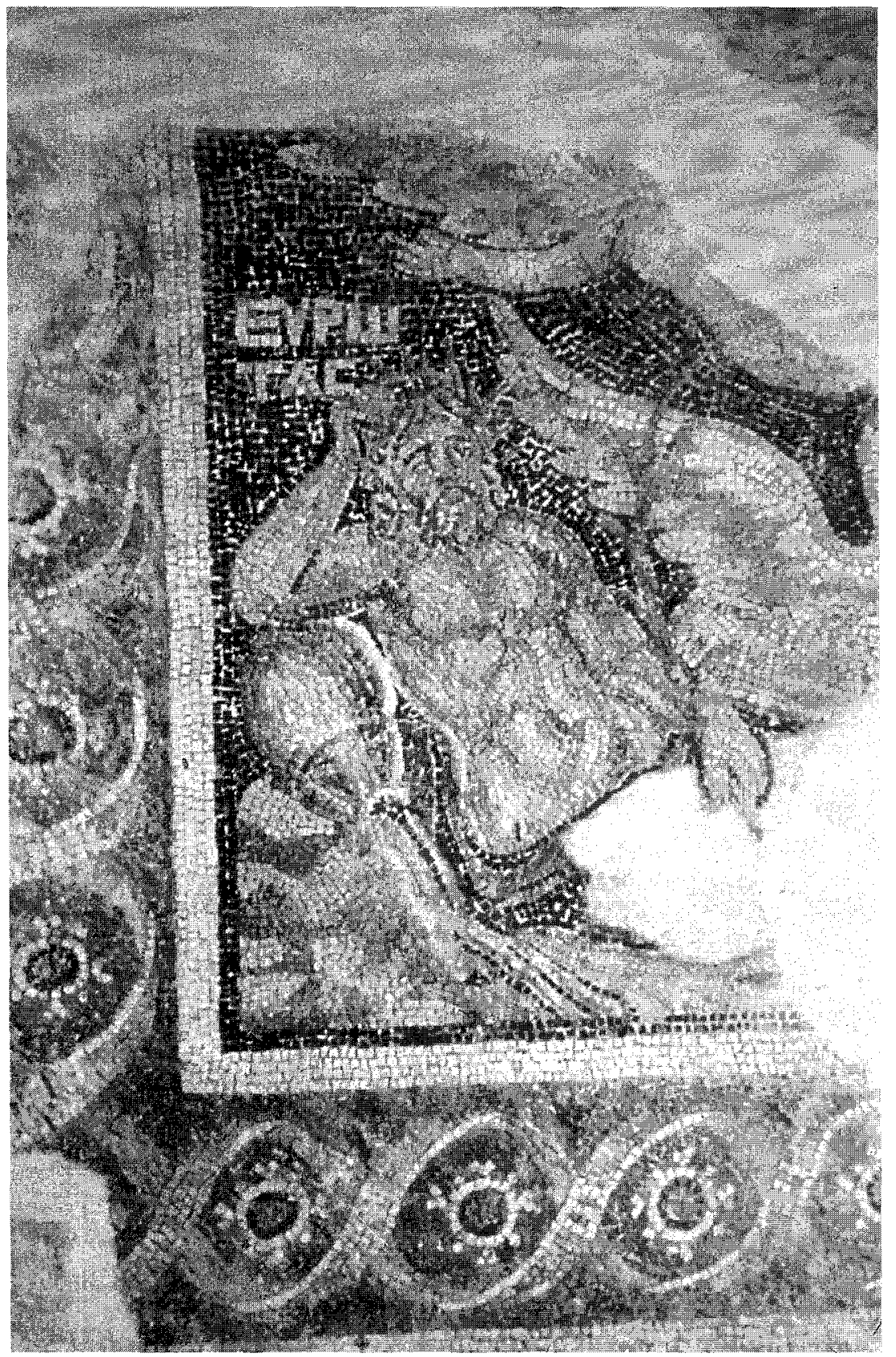

Fig. 9. Mosaico de Salamis. 


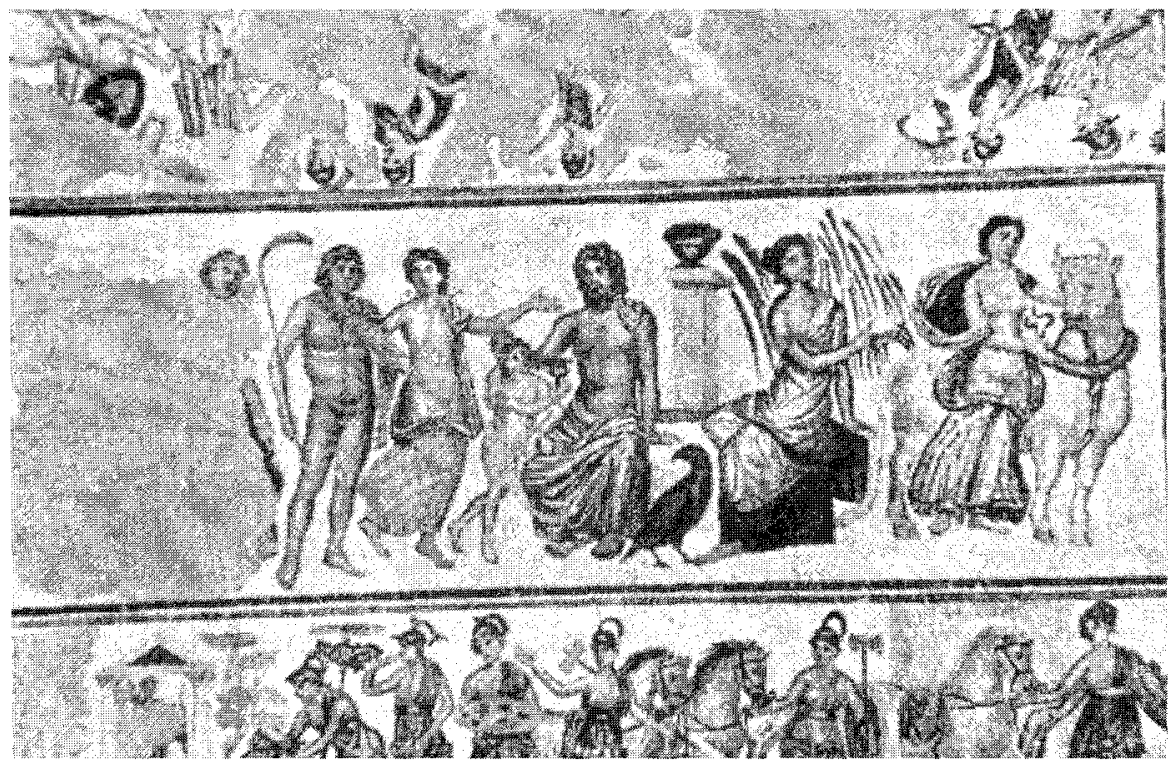

Fig. 10. Mosaico de Ouled Agla. Museo Nacional de Argel.

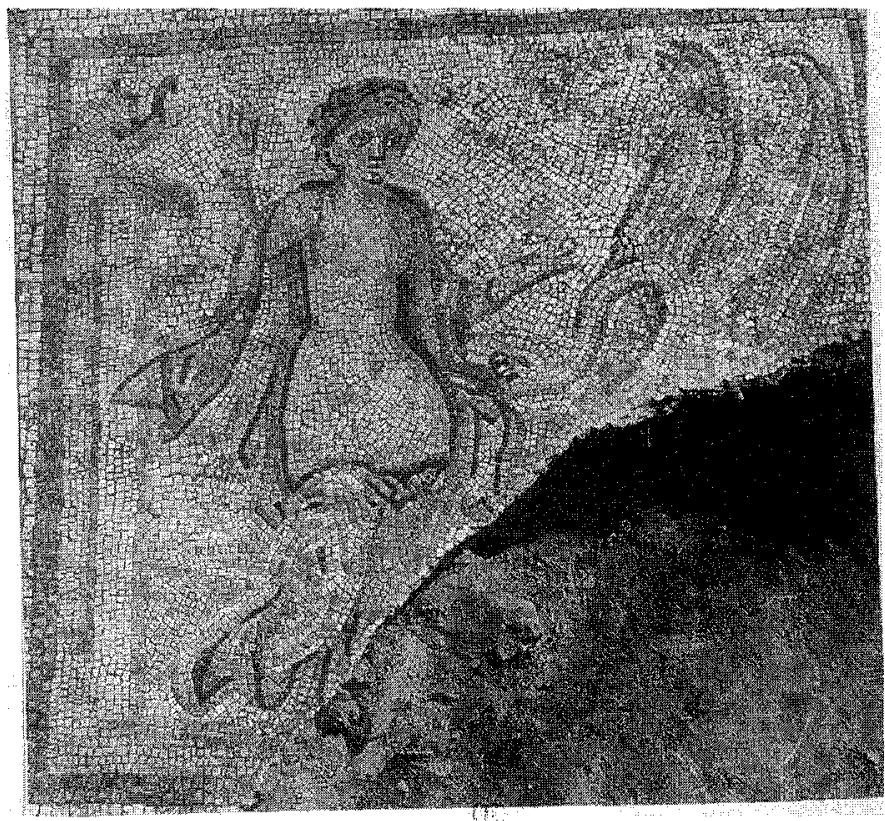

Fig. 11. Mosaico de Nîmes. Calle Pasteur. Museo Arqueológico de Nîmes. 
En los emblemas musivos con la escena de la huida de Leda se aprecian, aunque con algunas variantes iconográficas, el cambio efectuado en la princesa; ya no aparece ni relajada acariciando al ave, ni sorprendida o desconcertada, sino que, conociendo las intenciones del cisne, en actitud esquiva hace el gesto de apartarse o de forcejear con él, mientras el animal sujeta con el pico un extremo del manto de la joven intentando retenerla, al tiempo que ella trata de cubrirse.

A este grupo pertenecen cuatro interesantes pavimentos que muestran distintas secuencias consecutivas de la acción. En el ejemplar de Palermo, de la primera mitad del siglo III, que decoraba una capilla privada destinada a cultos mistéricos dionisiacos ${ }^{23}$, figura el grupo de Leda y el cisne junto con varias representaciones de los Amores de Júpiter (Zeus y Antiope, Dánae y la lluvia de oro, Europa y el toro), además de otros temas mitológicos. La princesa está vista de frente y desnuda, con la mano derecha en su pecho, en actitud pudorosa, mientras que con la izquierda, agarra el manto ya caído, que el cisne, con las alas levantadas, sostiene en su pico (Fig. 12).

En el mosaico en blanco y negro, fechado en la primera mitad del siglo III, que formaba parte del gran pórtico Oeste de la Casa Fulminata descubierta en Ostia, decorado con la representación de Venus con el espejo, diosa del amor, y otros geométricos ${ }^{24}$, se ha representado a Leda de frente, con las piernas cruzadas, en actitud de retirase hacia la derecha, sujetando el manto con ambas manos por detrás de su espalda, mientras que el cisne, como suspendido en el aire, probablemente para indicar mejor el gesto de retener a la princesa, le agarra el manto con su pico (Fig. 13).

En el mosaico hispano de Complutum (Alcalá de Henares), datado a finales del siglo IV o principios de $\mathrm{V}^{25}$, Leda, aunque aparece también de frente, inicia claramente como en el ejemplar ostiense un movimiento giratorio hacia la derecha para retirarse del animal, con las piernas cruzadas; lleva en su mano izquierda el tirso y con la derecha sujeta el manto que le cae por la espalda, cubriendo el hombro izquierdo y es sostenido

23 R. Camerato-Scovazzo, «Nuove proposte sul grande mosaico di Piazza della Vittoria a Palermo", Kokalos 21, 1975, 231-272; D. Boeselager, Antike Mosaiken in Sizilien, Roma 1983, 175-178, lám. LXI, fig. 123; G. CANUT1, «l mosaici con raffigurazioni delle stagioni in Italia», Atti del 1 Colloquio AISCOM, 1993, 102, n. ${ }^{\circ} 47$.

24 G. BecatTI, Scavi di Ostia. IV. Mosaici e pavimenti marmorei, Roma 1961, n. ${ }^{\circ} 204$, lám. CXIII.

25 D. Fernández-Galiano, Complutum, II. Mosaicos, Madrid 1984, 203-213, figs. 13-14, láms. CIX-CXII; J.M. BLÁZQUEZ et alii, «La mitologia en los mosaicos hispano-romanos», AEspA 59, 1986, 108-109, fig. 14. 


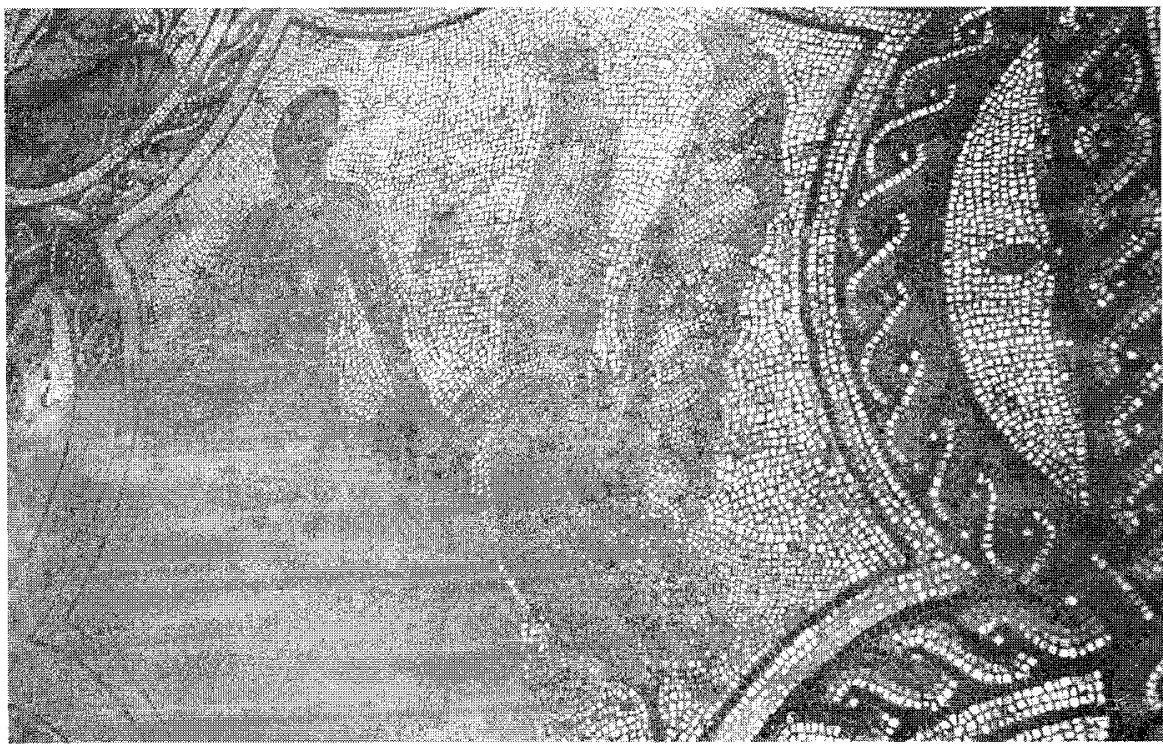

Fig. 12. Mosaico de Palermo. Piazza della Vittoria. Museo de Palermo. Foto G. López Monteagudo.

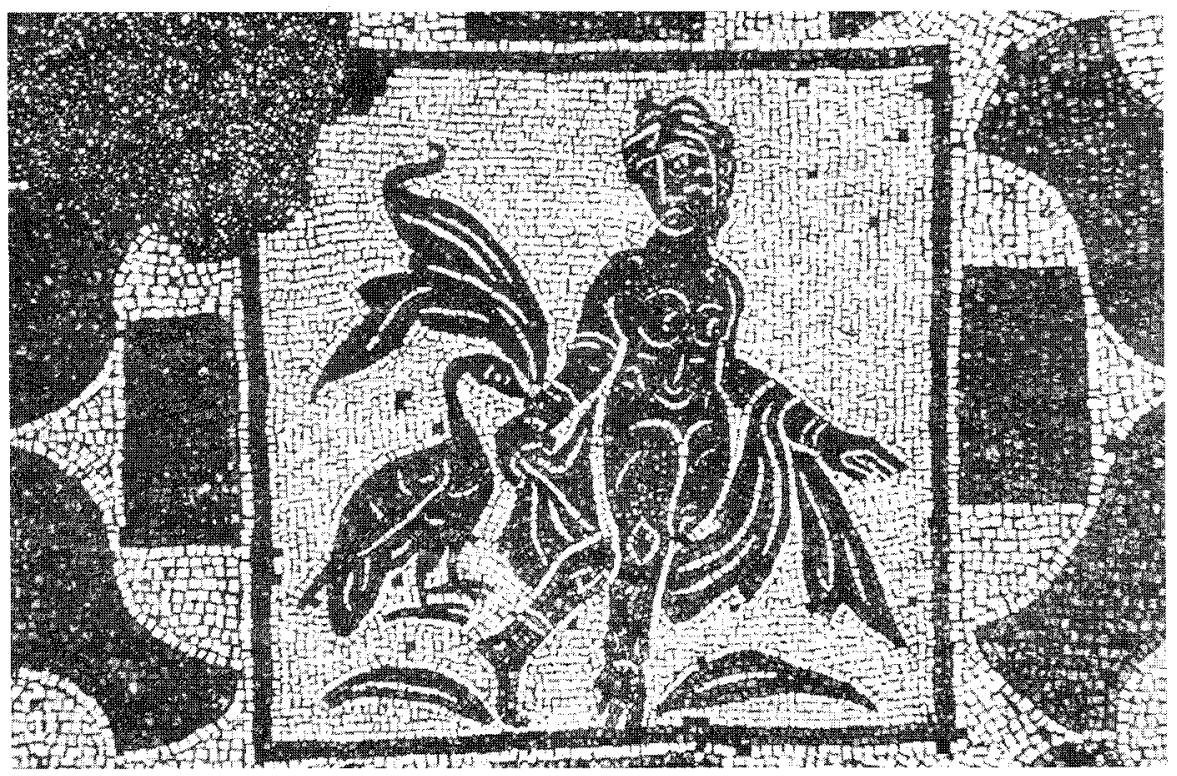

Fig. 13. Mosaico de Ostia. Casa Fulminata. 
con el brazo del mismo lado. A la izquierda el cisne, de pequeño tamaño, está posado sobre un ara y tiene las alas explayadas, en actitud de movimiento, sosteniendo el manto. Sobre ambos personajes aparecen dos guirnaldas colgadas de los ángulos superiores del emblema y del centro, elementos típicos de las obras pictóricas, así como una inscripción referente a la temática del cuadro (Fig. 14).

Aunque evidentemente el mosaico hispano escenifica el momento de la huida, sin embargo con la inscripción que aparece encima del cisne Adulterium / lovis y sobre la dama Leda, a la que hay que calificar por el momento de unicum dentro de su repertorio mitológico y solo comparable por la identificación de los personajes a través de sus nombres con los mosaicos de Nea Paphos (supra), Orthasia y Tréveris (infra), parece que se ha querido conjugar además el momento de la hierogamia sin representarla abiertamente como ocurre en el grupo de la unión amorosa (infra), por lo que constituye un ejemplo interesante de «representación abreviada", de forma que la imagen contiene en sí varios episodios o etapas del relato mítico.

El tipo iconográfico del cisne sobre un soporte o ara ${ }^{26}$, elemento decorativo de raíz escultórica, se encuentra ya en el arte griego de los siglos IV y III a. C., como en el lékitos ático que se conserva en el Museo de Boston o la sortija en oro procedente de Tarento, del Museo Nazionale de Nápoles pasando al mundo romano en relieves y pinturas, como la hallada en la Casa del Citarista ${ }^{27}$. En esta pintura pompeyana, la figura del ave posado sobre un pedestal y cogiendo el manto de la joven es muy similar al mosaico hispano, sin embargo aquí Leda, totalmente vestida con chiton e himation que le cubre la cabeza, está realizando un sacrificio junto a un santuario, mientras que en el cielo figura el águila persiguiendo al cisne (Fig. 15), iconografía que también se documenta en una copa etrusca de figuras rojas, del siglo IV a. C., procedente de Clusium (Chiusi) ${ }^{28}$ (Fig. 16).

El mosaico de Kouklia (Palaepaphos) que se conserva en el Museo chipriota de Nicosia, datado a mediados del siglo III, ofrece el momento inmediatamente posterior al de los pavimentos anteriores, cuando la princesa ya se ha girado. La imagen de Leda, a la cual se la ha identificado como Afrodita en el baño y su oca, se encuentra de espaldas, caminando

26 El ara es típica de las escenas de Leda delante del huevo de Némesis, de los vasos áticos, fechados entre 430 y 400 a. C., cf. LIMC VI, Leda, 1992, n. ${ }^{\circ} 28-32$.

27 LIMC VI, Leda, 1992, n. ${ }^{\circ} .3$ y $4 ; 61-65$.

28 Cf. nota 3 . 


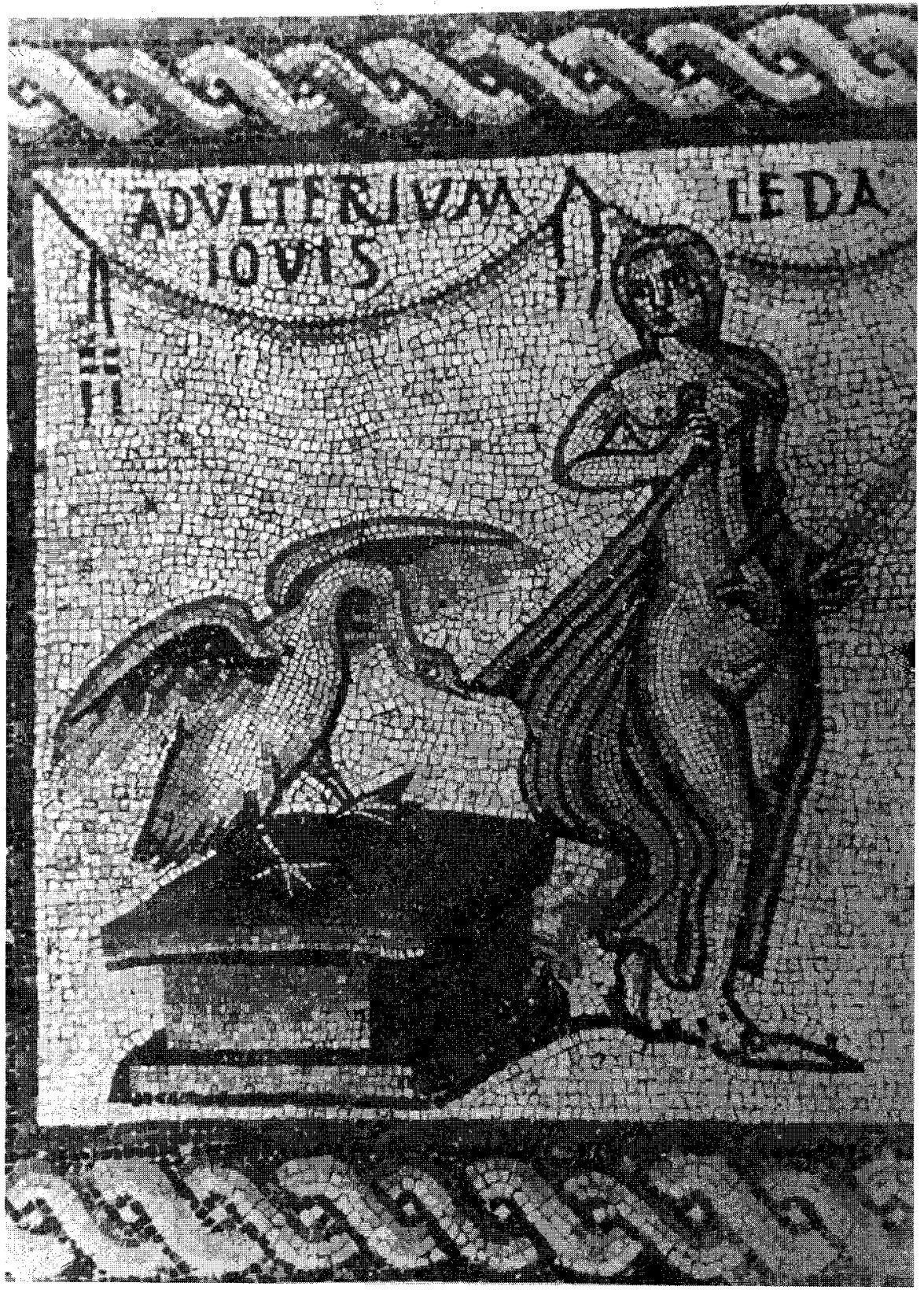

Fig. 14. Mosaico de Complutum (Alcalá de Henares, Madrid). 


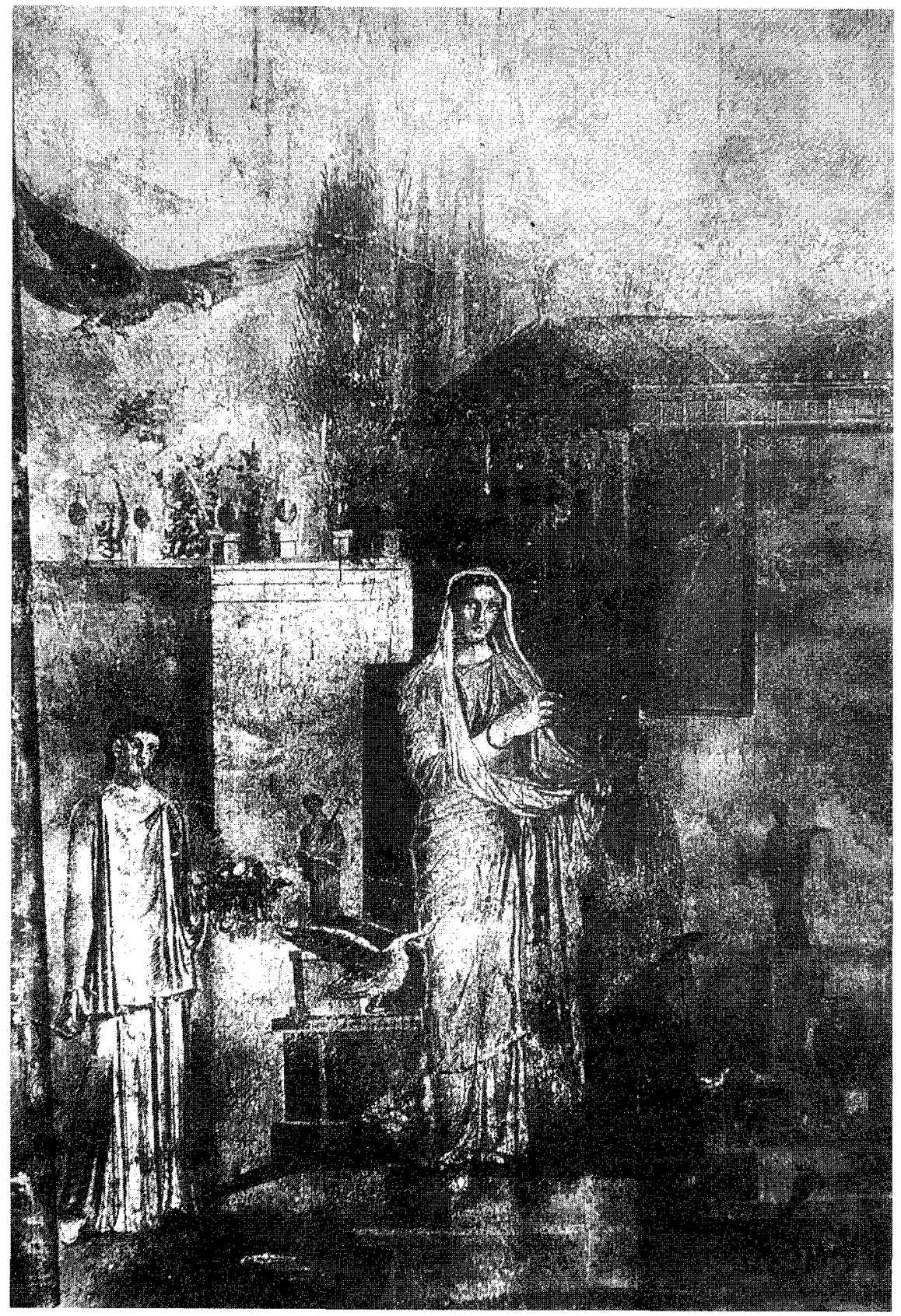

Fig. 15. Pompeya. Pintura de la Casa del Citarista. Museo Nacional de Nápoles. 


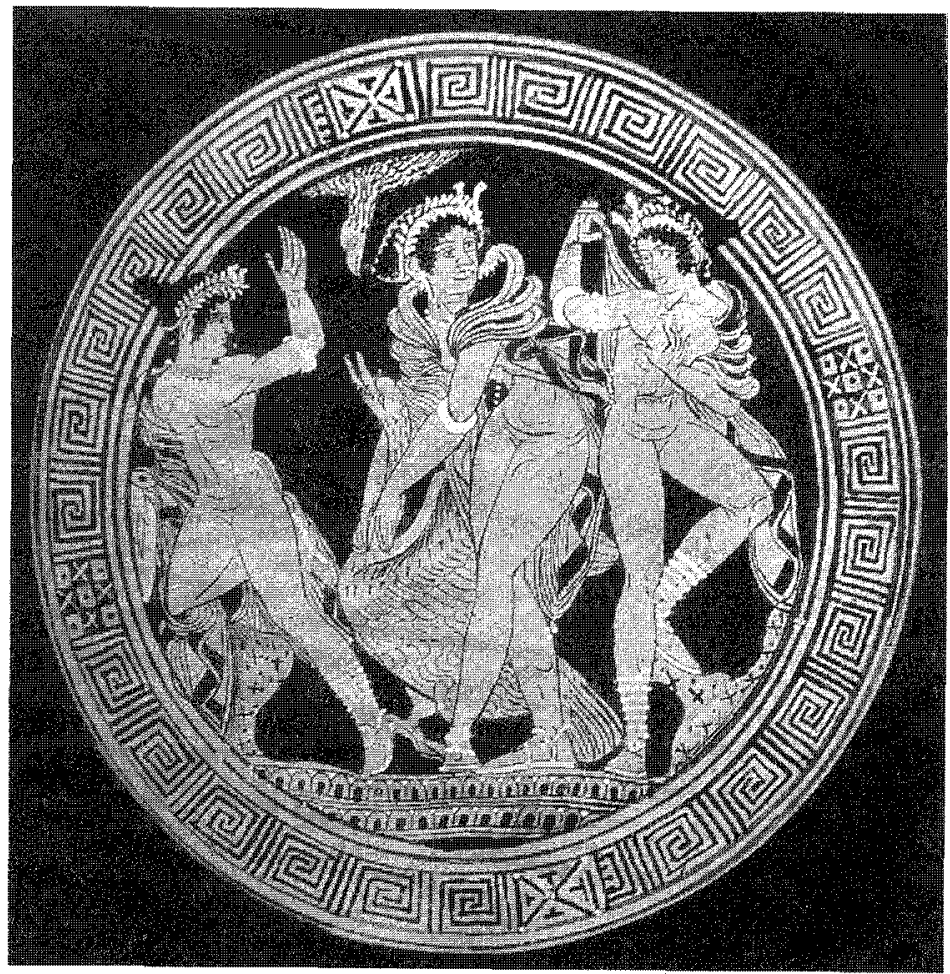

Fig. 16. Copa etrusca de Clusium (Chiusi). Museo de Arte e Historia de Ginebra.

por el agua, haciendo alusión al lugar en donde se produjo el encuentro como en el citado pavimento de Nea Paphos; viste strophion y manto que recoge con el brazo izquierdo dejando al descubierto su cuerpo desnudo. El cisne se encuentra a su derecha también en el agua, con la cabeza vuelta hacia la reina, quien a su vez vuelve la cabeza para atrás y, en actitud esquiva, forcejea con el ave que agarra el manto con el pico. Al igual que el pavimento de Antioquía presenta un paisaje con vegetación acuática $^{29}$ (Fig. 17).

29 F. G. MAIER, «Excavations at Kouklia (Palaepaphos). Sixth preliminary report. Seasons 1971-1972", RDAC, 1973, 194-197; Id., "Ausgrabungen in Altpaphos. Sechster vorlaüfiger Bericht», $A A 89,1974,43-48$; J. BALTY, «La mosaïque antique au Proche-Orient, I. Des origenes à la tétrarchie», ANRRW II, 12, 2, Berlin, Nueva York, 1981, 379-380; D. MiCHAELIDE, Cypriot Mosaics, Nicosia 1987, 21-22, n. ${ }^{\circ}$ 20, lám. 9; C. SALIOU, «Léda Callipge au pays d'Aphrodite remarques sur l'organisation, la fonction et l'iconographie d'une mosaïque de Palaepaphos (Chypre)», Syria LXVII, 2, 1990, 369-375. 


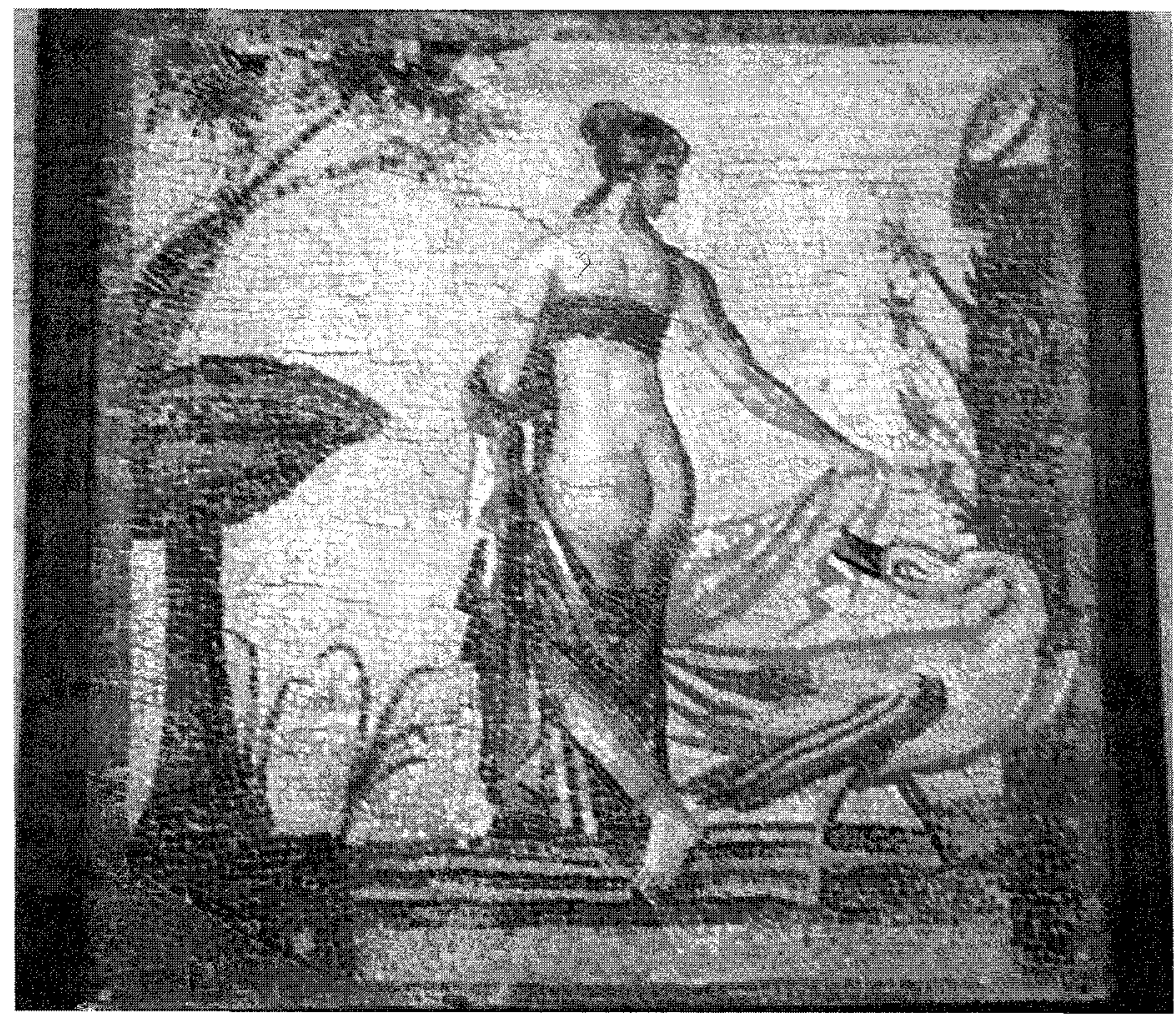

Fig. 17. Mosaico de Kouklia (Palaepaphos). Museo de Nicosia. Foto G. López Monteagudo.

La postura en pie y de espaldas de Leda se documenta también en el citado relieve copto (supra), que sería el paralelo más próximo del pavimento chipriota tanto para el gesto de la princesa como para la actitud del cisne; en un plato de plata del Tesoro de Seuso, fechado en el siglo V, aunque aquí el cisne se encuentra apoyado en un altar como en el pavimento de Complutum; y en los mosaicos de Suasa y de Ecija, figurando ya la fase de la unión amorosa (infra). En todos estos ejemplares destaca la ostentosa desnudez de la reina, pudiendo estar inspirados, como ocurre con la iconografía de Europa ${ }^{30}$, en una pintura helenística de Apeles que se distinguía por "la gracia» de su arte y por sus "personajes vistos de espaldas".

30 G. López Monteagudo, M.P. San Nicolás Pedraz, op. cit. (nota 10), 389-399. 
La segunda fase del mito o la unión amorosa, evocada en los textos literarios, es la más representada en relieves, pinturas, lucernas y terracotas, tanto del mundo griego como del romano. En ellos se aprecian diversas posturas y motivos, con una clara intención por parte del artista de resaltar el atractivo erótico de la leyenda, siendo característico un comportamiento del cisne semejante al humano, como demuestran algunas de sus actitudes: el abrazo, el beso o su pata sobre el cuerpo de Leda. En la musivaria romana se registran tres tipos iconográficos, Leda en pie, sentada o recostada, y en todos ellos las proporciones del cisne son del mismo tamaño que la joven como una manifestación del poder de la divinidad metamorfoseada, a la vez que el aspecto erótico se acentúa aún más al tratarse de una pareja más igualada.

Al primer tipo iconográfico pertenece el mosaico del cubiculum de la Casa de los Coiedii en Suasa, que se data a mediados del siglo III $^{31}$. A la derecha aparece Leda desnuda, en pie y de espaldas, avanzando su pierna izquierda hacia el cisne; lleva manto ondeado sobre el hombro derecho que desciende hasta la pierna izquierda, dejando al descubierto el resto del cuerpo. Con la mano izquierda intenta levantar la ropa ya deslizada, mientras que con la mano derecha extendida hace el gesto de agarrar el cuello del animal, posiblemente como última resistencia. A su izquierda está representado el voluminoso cisne, de perfil y con las alas explayadas, el cual flexionando el cuello busca con su pico los labios de Leda, mientras que con la pata derecha sobre el muslo de la princesa intenta atraerla hacia él. Debajo del ave, apoyado en el suelo, figura el rayo de Júpiter (Fig. 18). La representación de este atributo del dios, aunque se conoce en otras representaciones de los Amores como en el rapto de Ganímedes en el cazo hispano de Júpiter, de la segunda mitad del siglo III, hallado en el Faro de Cullera (Valencia) ${ }^{32}$ (Fig. 22), es un unicum en el repertorio artístico de Leda y el cisne, y sugiere claramente la presencia de la divinidad sin estar representada, al contrario que en el mosaico de Sousse, en el cual está figurado (infra).

La escena del pavimento de Suasa se repite en un mosaico procedente de una casa romana del siglo II, descubierta recientemente en el sub-

\footnotetext{
31 S. DE MARIA, «Suasa: un municipio dell'ager gallicus alla luce delle ricerche e degli scavi recenti", Atti del Convegno L'entroterra marchigiano nella Antichità: ricerche e scavi, (Arcevia 1991), Fano 1991, 35-37, fig. 21; G. CanUti, op. cit. (nota 23), 88, n. ${ }^{\circ}$ 22; P.L. Dall'AGlio-s. de María, "Scavi nella città romana di Suasa. Seconda relazione preliminaire (1990-1995)», Picus 14-15, 1994-1995, 1996, 144-147, fig. 22. S. DE MARíA, «Mosaici di Suasa: tipi, fasi, botteghe», Atti del III Colloquio AISCOM, 1996, 410-411, fig. 14.

32 M.L. Chofre Navarrete, "Trulla/ cazo de Júpiter hallado en el Faro de Cullera (Valencia)", Saguntum 28, (Homenatge al Prof. Dr. M. Tarradell i Mateu), 1995, 265-273.
} 


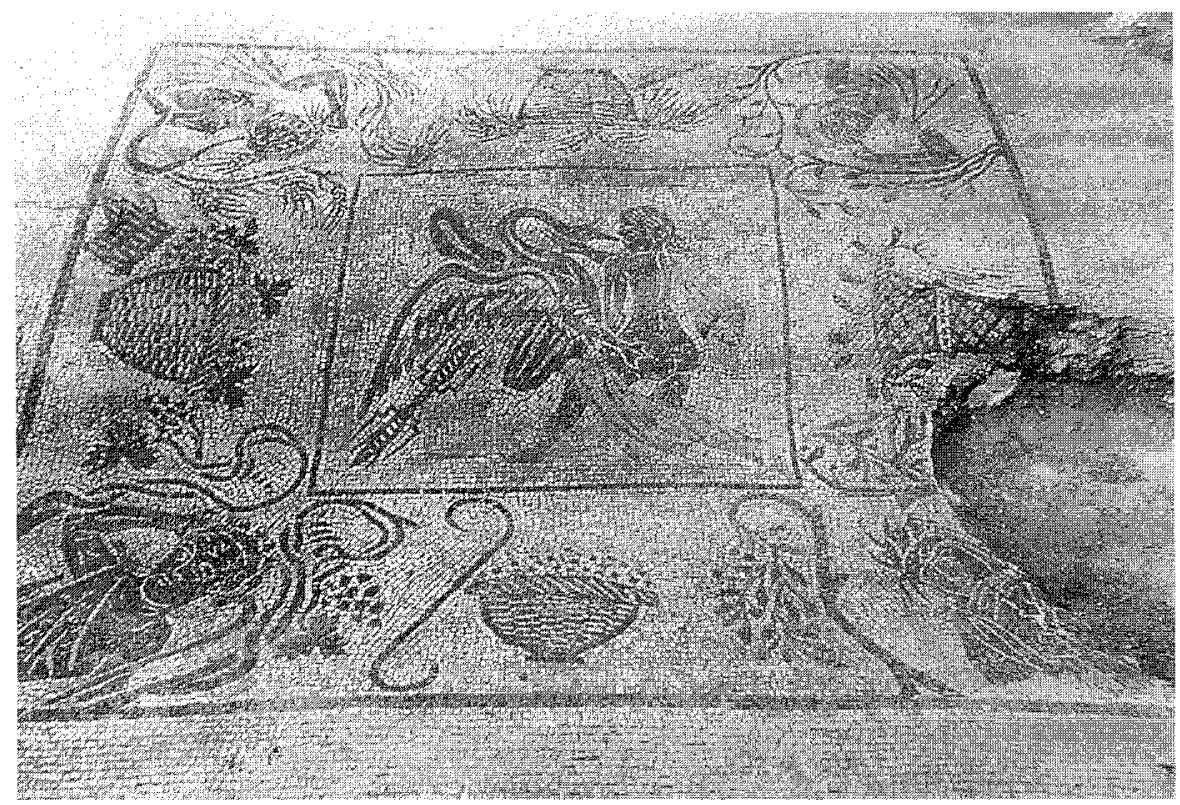

Fig. 18. Mosaico de Suasa. Casa de los Coiedii. In situ.

suelo de la Colonia Augusta Firma Astigi, con la particularidad de que el grupo de Leda y el cisne forma parte de una composición de carácter báquico ${ }^{33}$. La superficie del pavimento, de unos $15 \times 8 \mathrm{~m}$. de los que se conservan únicamente la mitad, presenta una composición a base de círculos y octógonos cóncavos en torno a un gran círculo central. Este gran medallón está decorado con el Triunfo de Baco de gran interés iconográfico al estar representado en un carro tirado por dos centauros y dos centauresas ${ }^{34}$. Los otros espacios conservados ofrecen diversas figuras del thiasos dionisiaco como las cabezas de Sileno y de Pan, bacante recostada sobre un kylix y sosteniendo el tirso y la crátera, sátiro corriendo con un gran kantharos, gacela, león, pantera, además de las personificaciones de la Primavera y el Verano, Leda y el cisne, Cástor y su caballo, Orfeo y Eurídice, Narciso sentado contemplando su imagen en el agua de la fuen-

33 F. Fernández Gómez, «Excavaciones de urgencia del Museo Arqueológico de Sevilla en la ciudad de Écija», Boletín de la Real Academia de Ciencias, Bellas Artes y Buenas Letras "Velez de Guevara» 1, 1997, 75-80; Id., "Nuevos mosaicos romanos en Ecija (Sevilla)», Rev. de Arq. n. 207, 1998, 32-41.

34 G. López MONTEAgUdo, «Sobre una particular iconografía del Triunfo de Baco en dos mosaicos romanos de la Bética», Anales de Arq. Cordobesa 9, 1998, 192-195, lám. 1.1. 
te, y la cola de un delfín montado por un eros. La escena de la princesa etolia, reina de Esparta, Leda figura en pie y de espaldas, con el talón izquierdo ligeramente levantado, y por tanto también la rodilla, síntoma de sutil resistencia; va totalmente desnuda excepto las piernas que cubre con un manto transparente; con la mano derecha sujeta el manto que ondea por detrás de la espalda, mientras que, al igual que en el pavimento de Suasa pero en posición invertida, agarra el cuello del cisne con la mano izquierda. Aquí el animal está aún suspendido en el aire como dando un impulso (Fig. 19).

Dentro del repertorio artístico de Leda y el cisne, la iconografía de la princesa de espaldas en el mismo momento de ser poseída por el ave solo se documenta, hasta el momento, en la musivaria romana, siendo por tanto los pavimentos de Suasa y de Ecija ejemplares únicos. Sin embargo la escena puede ponerse en relación con las distintas variantes del grupo en donde el cisne, de aspecto voluminoso, se abalanza contra Leda para poseerla, aunque ambos personajes están vistos de perfil, encontrándose documentado en lucernas, relieves, esculturas y pinturas, de los siglos I-III, cuyos antecedentes aparecen en el arte griego, en un relieve procedente de Cnosos, del Museo de Iraklion, y en otro de Argos, del siglo III a. C.; en este último, conservado en el British Museum, se repre-

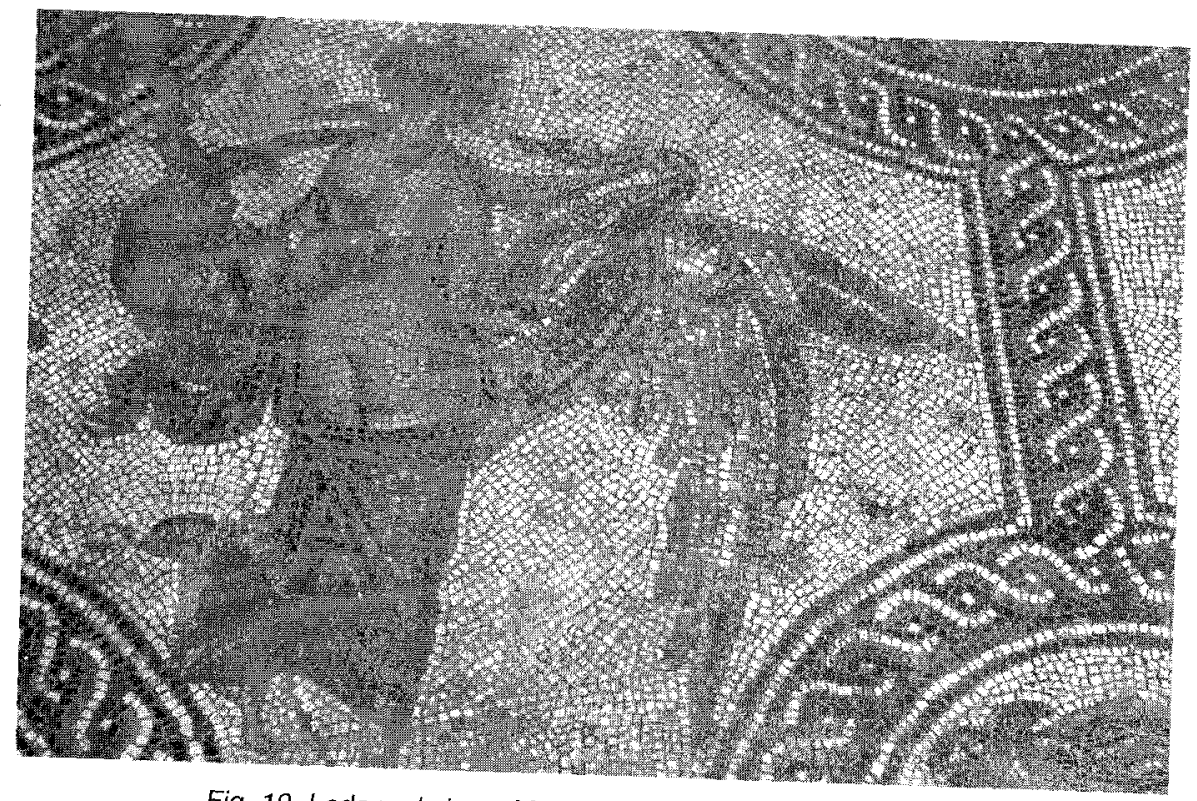

Fig. 19. Leda y el cisne. Mosaico de Ecija. Foto F. Fernández. 
senta la variante de que el cisne somete a la mujer apretando su cuello con el pico ${ }^{35}$. Aunque la finalidad del cisne es la misma en ambos mosaicos, imponer su poder divino cumpliendo su deseo de poseer a la joven, sin embargo existe una clara diferencia en su postura que señala dos variantes. Respecto al mosaico de Ecija el animal está representado en el momento mismo de abalanzarse sobre ella, iconografía que aparece en la ya citada pintura de Herculano conservada en el Museo de Nápoles, mientras que en el de Suasa la pata del animal aparece ya sobre el cuerpo de Leda como se apreciaba en la perdida pintura pompeyana de la Casa de Meleagro o en el citado relieve de Argos. Estas variantes iconográficas, así como la desnudez y actitud de la joven agarrando el cuello del cisne y levantando el talón indicando una sutil resistencia o un preludio de intervención activa, son detalles que acentúan aún más el carácter erótico del tema, pudiendo decirse que estas escenas serían como las primeras secuencias, incluso consecutivas, de las representaciones del grupo de la unión entre Júpiter y Leda.

Una de las particularidades del mosaico astigitano, que no se encuentra en los restantes pavimentos, es la presencia en otro de sus recuadros del joven Cástor. En la tradición literaria Cástor y su hermano Pólux son conocidos por varios nombres. Los Tindáridos, apelativo de origen lacónico o mesénico (Paus. III 26, 3; IV 16, 5; IV 27, 6), hijos del rey Tindareo; los Dióscuros denominación de origen jónico, cuyo testimonio más antiguo aparece en una inscripción de Thera, datada a finales del siglo VIII o principios del VII a. C. (IG XII 3, 359). En el segundo Himno homérico (33), del siglo VI a. C., a los Dióscuros se les nombra a la vez hijos de Zeus y Tindáridos, nacidos de Leda; para Pindauro ( $P$. IV 171-173) también fueron hijos del dios, aunque este mismo autor considera igualmente a Cástor hijo de Tindareo (Nem. X 78-82). En Roma los Dióscuros griegos pasan con el nombre de Castores, plural que atestigua la primacía de Cástor sobre la de su hermano; su culto se introduce en el Latium y en la Urbs directamente de la Magna Grecia (Cumas, Locris o Tarento) desde principios del siglo V a. C., como se aprecia en la inscripción hallada en Lavinium ${ }^{36}$.

El nombre de Cástor, aunque de origen indoeuropeo, proviene directamente del griego Kastor (Varrón I. I. 5, 73) y se le conoce como el doma-

35 J. Deneauve, Lampes de Carthage, Paris 1969, 166, lám. 68; C. Johns, Sex or symbol. Erotic images of Greece and Rome, Londres 1982, láms. 4, 21 y 88; LiMC VI, Leda, 1992, n. ${ }^{\circ} 15-$ 16, 76-101.

36 R. BLoCH, "Nouvelle inscription de Lavinium», BullSAntF 1959, 281-283; Id., "L'origine du culte de Dioscures à Rome", RPh 34, 1960, 182-193; F. GASTAGNOLI et alii, Lavinium II. Le tredici are, Roma 1975, 443 ss; Id., «L'introduzione del culto dei Dioscuri nel Lazio», StRom 31, 1983, 3-12. 
dor de caballos (Hom. II. III, 237; Od. XI 300), pasando al mundo romano, por su naturaleza guerrera (Pind. P. XI, 61; Apoll. Bibl. II 4, 9; Poly. I 10; Plut. de mus. 1140c; Lyc. 22), como modelo y patrón de los equites. Recibió, como indican Pausanias (III 13,1) y Plutarco (quaest. graec. 269f), culto por separado de su hermano Pólux, en Esparta, y se le dedicó en Roma el templo del Forum (Liv. II 42, 5) ${ }^{37}$. En Hispania, concretamente en la epigrafía de la Bética, aparece solo el nombre de Pólux (CIL II, 2100).

En el recuadro del pavimento de Ecija, el jinete Cástor está representado visto de frente, delante del caballo, desnudo, con chlamis en la espalda que cae sobre su hombro izquierdo; aparece tocado con el pileus y con la estrella encima de la cabeza, su atributo principal como divinidad celeste, en alusión a su hemisferio y constelación (Sextus Empiricus math. IX 37) ${ }^{38}$. Con la mano derecha sujeta la lanza mientras que con la izquierda agarra las riendas del animal, el cual figura en posición lateral, mirando hacia la izquierda, iniciando el paso (Fig. 20). El tipo iconográfico de este grupo es bastante frecuente en el mundo romano desde el siglo I y sobre todo en el II, tanto con las representaciones de ambos Dióscuros o sólo con la figura de Cástor como se documenta en las monedas de Marco Aurelio ${ }^{39}$. En la musivaria los Dióscuros aparecen representados en varios ejemplares con una iconografía diferente. Se encuentran en el pavimento del Triunfo de Diónisos de la Casa de Diónisos en Nea Paphos, fechado entre 250 y $300^{40}$, con la particularidad que aquí ambos hermanos figuran en pie delante de sus caballos, sin la estrella en la cabeza pero coronados con una diadema de laurel, signo de victoria, aspecto mencionado en Floro $(138,20)$, así como también por sus innumerables batallas relatadas en las fuentes literarias, batalla de Pydna (Val. Max. I 8, 1; Cic. Nat. 2, 6), batalla de Farsalia (Cas. Dio. 41,61 ) ${ }^{41}$; en el mosaico de la Casa de los Caballos, ca. 320-330, aparecen, en un segundo plano, también en pie con chlamis en la espalda, figurando solo un caballo como signo de la Casa al igual que el resto de los cuadros del pavimento ${ }^{42}$; en el mosaico de la Casa de los Dióscuros de Ostia, de finales del siglo IV, también en pie pero sin sus caballos y con el pileus estrellado, junto a la

\footnotetext{
37 R. BLOCH, Templum Castoris, BullSAntF 1980-1981, 35-46.

38 Para este particular cf. F. CUMONT, Recherches sur le symbolisme funéraire des romains, Paris 1966, 64-103.

39 LIMC III, Dioskouroi, 1986, n.․ 34-73, 80-91, 93-96 (68 y 68a monedas).

40 V.A. Daszewki y D. Michaelides, op. cit. (nota 7), 222-225, fig. 7.

41 LIMC III, Castores, 1986, 608-609.

42 J. Salomonson, La mosaíque aux chevaux de l'Antiquarium de Carthage, La Haye 1965, 125, n. ${ }^{\circ} 60$, fig. 64 , lám 51, 1; K.M.D. Dunbabin, op. cit. (nota 4), 95-96.
} 


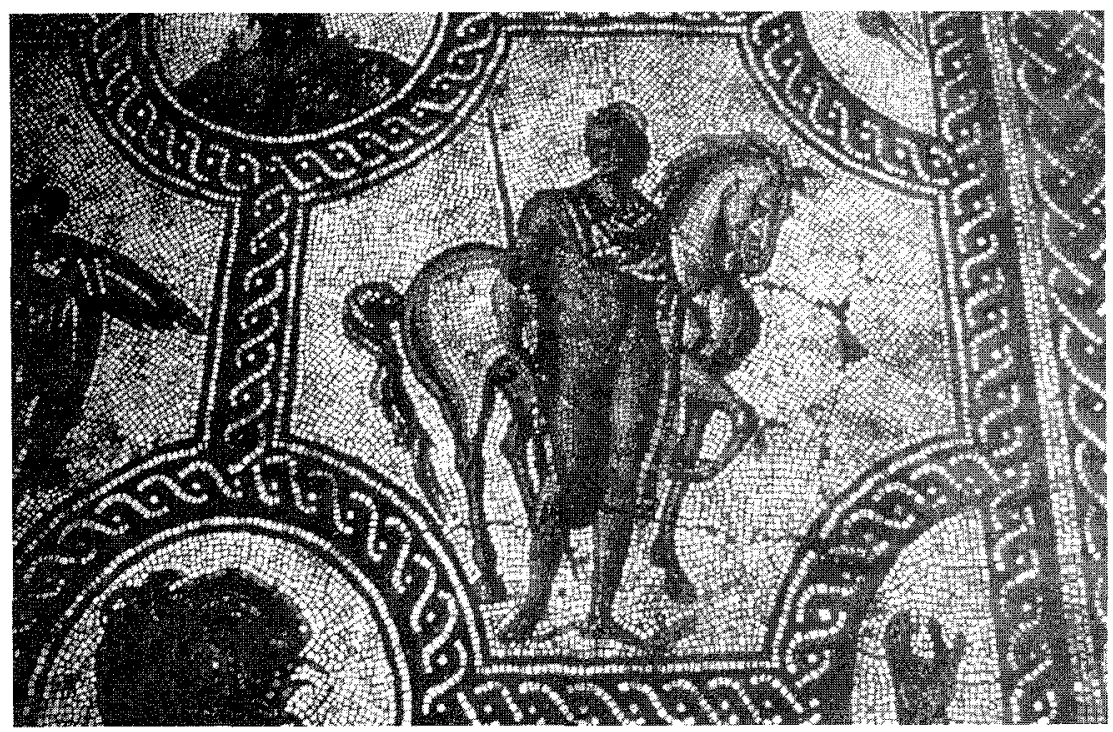

Fig. 20. Cástor. Mosaico de Ecija. Foto F. Fernández.

Loba y los gemelos Rómulo y Remo ${ }^{43}$, alegoría romana de la eternidad; mientras que en el pavimento del Mitreo de Felicissimus de Ostia, de mediados del siglo III, se sugiere su presencia al estar representados junto a un vaso sus pilei y encima la estrella, como divinidades astrales y cósmicas en relación con un culto mitraico ${ }^{44}$. Igualmente los símbolos de los Dióscuros aparecen en un mosaico siciliano hallado en Tyndaris (Messina), fechado en el siglo $1 \mathrm{l}{ }^{45}$.

En el mosaico hispano de la villa Quintanilla de la Cueza (Palencia), habitación 24 , fechado en el siglo IV, que se conserva in situ ${ }^{46}$, también se ha representado el episodio del mito de la unión de Leda y el cisne. Del mosaico que mide $6,50 \times 6,50 \mathrm{~m}$., se ha conservado del emblema central el busto de la princesa, de frente, con el manto que se infla por detrás de la espalda, a efectos sin duda del impulso tomado por el animal al saltar sobre ella; con la mano izquierda agarra el cuello del cisne, apretándolo contra sí (Fig. 21).

43 G. BECATtI, op. cit. (nota 13), 117-118, n. ${ }^{\circ}$ 216, lám. 201. En Ostia, al igual que en Roma los Dióscuros fueron venerados, asociados a Neptuno, como protectores de la navegación, celebrándose en su honor la fiesta de la Neptulia, el 23 de julio; incluso a finales del siglo $\mathrm{V}$ aún seguían existiendo fieles en Ostia, como se lamenta el papa Gelario (Gelasius tract. 6, 8).

44 G. BecatTI, Scavi di Ostia II, I. Mithrei, Roma 1954, 106-107, fig. 22; Id., op. cit. (nota 13), 117-118, n. ${ }^{\circ} 216$, lám. 201.

${ }_{45}$ U. SPIGo, "Tyndadris Messina», en A.M. Bietti Sestieri et alli (ed.), Sicilia orientale e isole Eolie, Foli 1995,161 y fig. 


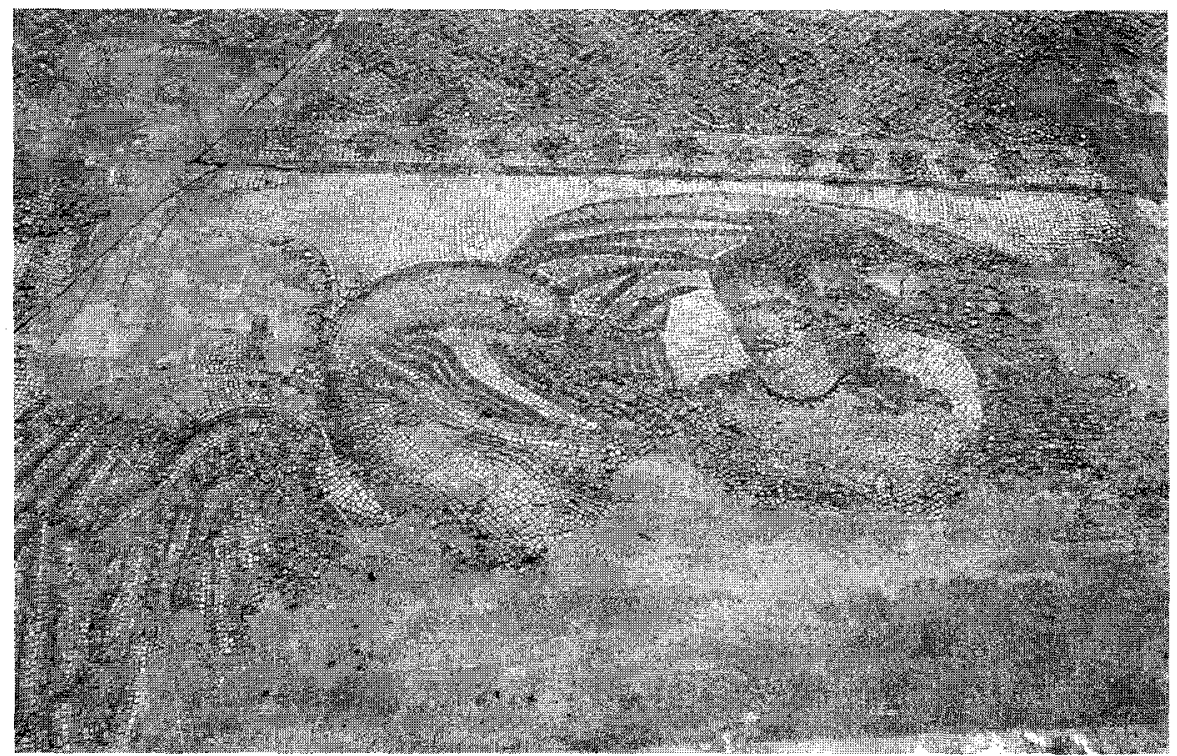

Fig. 21. Mosaico de Palencia. Villa de Quintanilla de la Cueza. In situ. Foto G. López Monteagudo.

Las particularidades más sobresalientes de esta representación son la transformación de Leda, ya no aparece joven y bella como la mencionan los mitógrafos (Hes. frag. 23. A8), sino que tiene aspecto de una mujer madura, de labios voluminosos y carnosos, con el pelo caído sobre los hombros; y el cambio de la posición de su manto que se convierte en una figura velificante sua manu, iconografía poco usual en su repertorio artístico, de la que solo se conoce, hasta el momento, la destruida pintura pompeyana de la Casa de la Reina Margarita ${ }^{47}$, y que se podría enlazar con los ejemplares que tienen el manto arqueado detrás de la espalda, como en el mosaico de Baccano.

46 A. BALIL, «Algunos mosaicos de tema mitológicos», BSAA LV, 1989; J.M. BLÁzQUEZ et alii, op. cit. (n. ${ }^{\circ}$ 25), 109; M.A. GARcia GuINEA, Guía de la Villa Romana de Quintanilla de la Cueza, Palencia 1990, 24-25, 35-37, 40; J. Cortés Álvarez de Miranda, Rutas y villas romanas de Palencia, Palencia 1996, 128; M.A. García GuInEA, La villa romana de Quintanilla de la Cueza (Palencia). Memoria de las excavaciones 1970-1981, Palencia 2000, 261-266. A los lados del pavimento de Leda y el cisne existen dos mosaicos muy deteriorados en los que estaban representadas otras figuras míticas, conservándose la cabeza de Océano inscrita en un cuadrado. Curiosamente los atenienses afirmaban que Océano era el padre de Némesis (Paus. Descr. Grec. VII 5, 3); por otra parte la iconografía de la mujer en el mosaico hispano se aparta del tipo habitual, pues Leda es, además de bella, al contrario de Némesis, luz, claridad y, sobre todo humana, aspecto posiblemente aquí señalado en la madurez de la mujer.

47 E.M. MoonmanN, La Pittura parietale romana come fonte di conoscenza per la scultura antica, 1988, 165-166, n. ${ }^{\circ} 190$, fig. 190. 
Los paralelos más próximos para la postura de Leda abrazando al cisne del ejemplar hispano se encuentran en las citadas pinturas de la Casa de Meleagro en Pompeya y de Herculano, así como en el cazo de Júpiter de Cullera (Valencia), junto a otras representaciones de los Amores: Semele, Calisto, Ganímedes y Leda ${ }^{48}$ (Fig. 22). En este ejemplar de plata, conservado en el Petit Palais de Paris, está representado en el asa el mismo Júpiter, presidiendo las escenas de sus Amores, con la iconografía clásica de hombre maduro, portando en su mano izquierda el cetro y en la derecha el rayo, símbolo éste último que aparece, como ya hemos señalado en el mosaico de Suasa. Sin embargo, la particularidad iconográfica más sobresaliente de la escena de Leda y el cisne de este cazo hispano es la presencia y el cambio efectuado en la figura de Eros; ya no aparece sosteniendo la antorcha o señalando a la pareja para resaltar el atractivo amoroso, como en los mosaicos de Lambaesis, Antioquía o Salamis que representan la primera fase del mito, sino que, de forma más activa, les induce a la pasión empujando al ave hacia delante como en el citado relieve de Cnosos. Sobre Eros figura un objeto rectangular que ha sido interpretado como un estuche de aseo o un joyero.

En la musivaria norteafricana esta iconografía del momento de la hierogamia de Leda y Júpiter, transformado en cisne, se representó con algunas variantes en el mosaico de Sousse, datado a mediados del siglo II, el cual pavimentaba la habitación de una casa supuestamente destinada a un cubiculum, junto a otro episodio de los amores del dios, Ganímedes y el águila ${ }^{49}$, como en el mosaico de Baccano. La escena de Leda y el cisne representa un grupo escultural, figurando ambos personajes sobre un podium o ara cuadrada en la que está apoyada una figura masculina, posiblemente el propio Júpiter. Leda en pie, con la cabeza, hoy perdida, estaría inclinada sobre el cuello del cisne, mientras que éste, representado en gran tamaño, picotea la nuca de su compañera, (Fig. 23).

Esta variante iconográfica de la postura de Leda sobre el cuello del cisne, a la vez que éste la somete apretándole el cuello con el pico, se documenta ya en el arte griego del siglo III a.C., en el citado relieve de Argos, pasando al mundo romano como puede verse en los relieves de los siglos I-III ${ }^{50}$. También de este tipo es un relieve hispano de la colec-

\footnotetext{
48 M.L. Chofre Navarrete, op. cit. (nota 32).

49 L. FouCHER, «Inventaire des Mosaïques de Sousse», Túnez 1960, 21, n. ${ }^{\circ} 57.044$, lám. IX, b; DunBabin, op. cit. (nota 4), 269.

50 C. JoHns, op. cit. (nota 35), lám. 21; LIMC VI, Leda, 1992, n. ${ }^{\circ} 15,99-101$.
} 

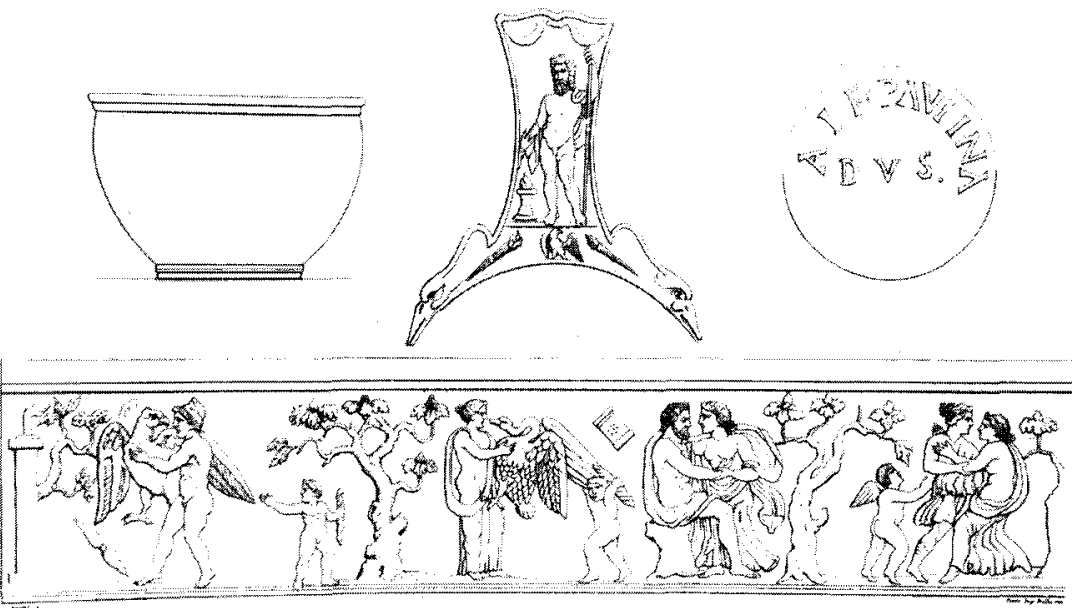

Fig. 22. Cazo de plata. Faro de Cullera (Valencia). Museo del Petit Palais, Paris.

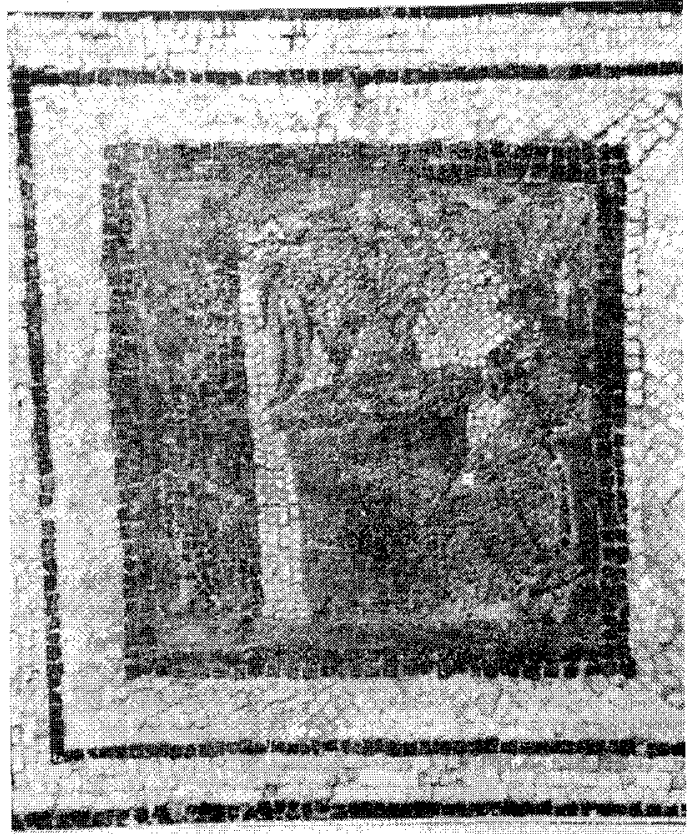

Fig. 23. Mosaico de Sousse. Casa de Ganímedes. 
ción Medinaceli que se conserva en la Casa de Pilatos de Sevilla ${ }^{51}$, con la particularidad iconográfica de tener representada una palmera.

En cuanto a la presencia del mismo Júpiter, aunque rara, no es desconocida en el repertorio musivo de sus «Amores", como demuestran las escenas de la seducción de Dánae en los pavimentos de Itálica, Beyrouth y Carthago ${ }^{52}$, y aquí, al igual que en ellos, indicaría el momento mismo de la fecundación a través de su metamorfosis.

El segundo tipo con la hierogamia de Leda y el cisne, aparece en el pavimento de unas termas de Ouled Haffouz (Túnez), fechado en el siglo VI ${ }^{53}$, siendo por tanto, hasta el momento el ejemplar musivo más moderno del tema mitológico. En este mosaico, que se encuentra muy deteriorado, el grupo aparece junto a otras figuras como Venus, diosa que está representada también cerca del mosaico de la Casa Fulminata de Ostia, un personaje femenino sin identificar, Cupido, un protomo de toro y la parte trasera de un asno, además de varias inscripciones. Identificados por sus nombres están (L)eda, Cicinu ( nombre latino tardío del latín clásico cycnus), Cupido, igualmente aparece parte del nombre de Diana y una inscripción de difícil interpretación Osedas num labas, apóstrofe dirigido al invidus. A la izquierda del panel está representada Leda, sentada, con el busto de frente, las piernas de perfil y cruzadas acogiendo en ellas al ave, mientras que con la mano izquierda le abraza y le aprieta contra ella con el fin de ayudarle en la acción amorosa. Está adornada con perlas como en el mosaico de Nea Paphos, pendientes, collares y un tocado a lo largo de la raya central del peinado. El cisne figura a su lado izquierdo, de perfil y flexiona el cuello buscando los labios de Leda; las alas ya no aparecen extendidas o levantadas en actitud de movimiento, sino que están plegadas, indicando relajación por estar cumpliendo su deseo de poseer a la joven (Fig. 24).

Aunque el modelo iconográfico de Leda sentada de este pavimento es un unicum en la musivaria romana, sin embargo no es desconocido en su repertorio mitológico, encontrándose tanto en el arte griego como en el romano, en esculturas, pinturas, sarcófagos, joyería y terracota ${ }^{54}$, pero en ninguno de estos ejemplares es tan evidente el momento erótico del tema

\footnotetext{
51 S. REINACH, Répertoire de reliefs grecs et romains, Paris 1912, vol. II, lám. 192, n. ${ }^{\circ} 15 \mathrm{~F} ; \mathrm{F}$. BRoMmer, Denkmälerlisten zur griechischen Heldensage, Marburgo 1976, vol. III, 211, n 18; H. WIEGARTZ, op. cit. (nota 15), 172.

52 G. López MONTEAGudo, "El mito de Perseo en los mosaicos hispanos. Particularidades hispanas». Espacio, Tiempo y Forma 11, Serie II, 1998, 439-443.

53 N. JEDDI, Une mosaïque inédite d'Ouled Haffouz (Tunisie), MGRIV, 1994, 273-279, láms. CLXXIX-CLXXXI.

${ }_{54}$ LIMC VI, Leda, 1992, n. ${ }^{\circ} 20-23,102-106$.
} 


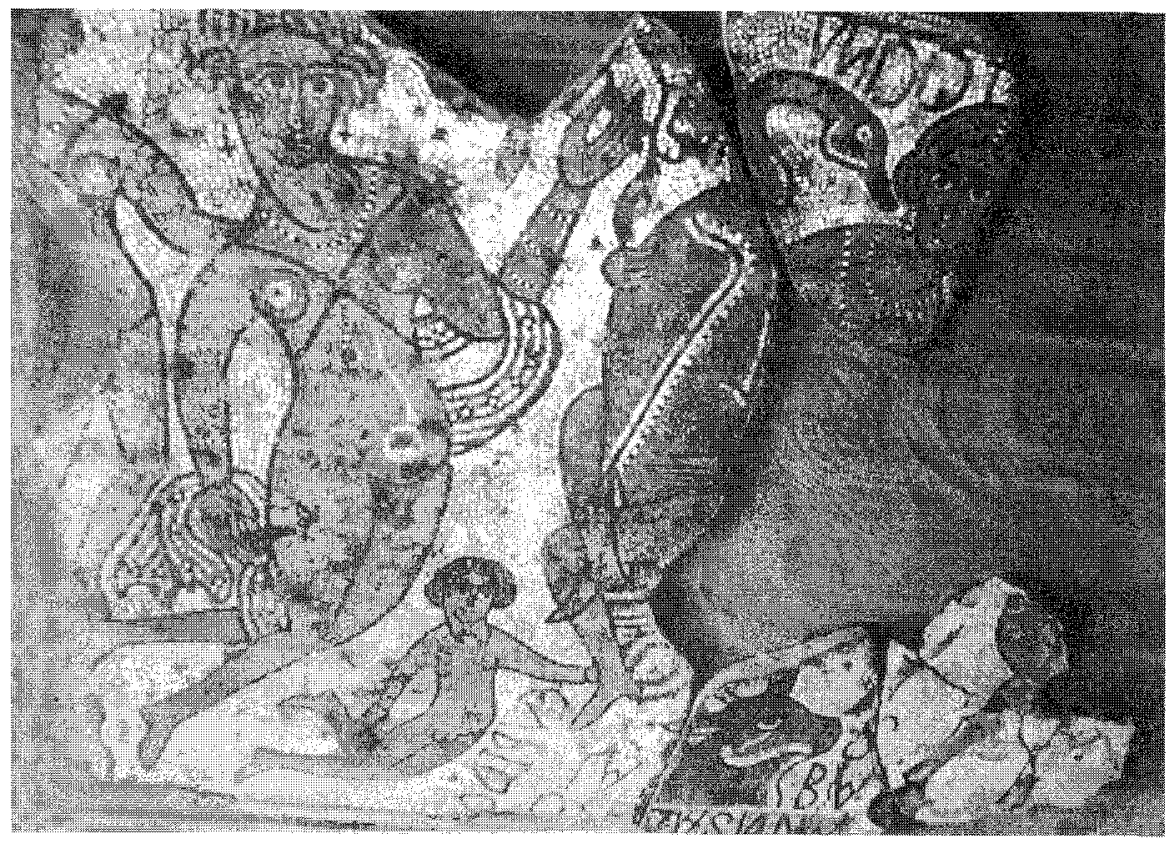

Fig. 24. Mosaico de Ouled Haffouz, Túnez.

como en este mosaico tunecino, cuyo estilo artístico se emparenta con la musivaria oriental, concretamente con la de la ciudad de Madaba.

El tercer tipo con la hierogamia de Leda y Júpiter, donde la princesa etolia, completamente desnuda, ya no está de pie o sentada sino recostada y sobre ella el ave, a quien acoge entre sus piernas flexionadas, se halla atestiguado en cinco pavimentos romanos. Este tipo iconográfico fue el más representado entre los artistas romanos que lo plasmaron en pinturas, sarcófagos, relieves, esculturas, gemas y lucernas, con gran amplitud cronológica, cuyo antecedente aparece en el arte griego entre los siglos IV y I a.C., perdurando hasta el siglo V como demuestran los relieves coptos de Alejandría ${ }^{55}$, en donde se ha intentado explicar la presencia de Leda en un contexto cristiano como una recuperación del mito para simbolizar la Inmaculada Concepción ${ }^{56}$.

55 C. JoHnS, op. cit. (nota 35), lám. 89; LIMC VI, Leda, 1992, n. ${ }^{\circ}$ 24-27; 122-125; C. GASPARRI, Le gemme Farnese, Nápoles 1994, 43, n. 53.

56 Estos relieves tardíos del arte copto no proceden de excavaciones sistemáticas, por lo que es difícil su interpretación, para algunos autores son obras de un templo pagano próximo a otro cristiano, para otros fueron hallados en necrópolis en las que se enterraban indistintamente 
En la musivaria romana este tipo del momento mismo de ser Leda poseída por el cisne, ofrece dos variantes iconográficas que documentan dos secuencias del mismo. La primera de ellas el cisne aproxima su pico sobre el rostro de Leda para besarla y la otra parece ser el momento mismo del beso.

Al primer grupo iconográfico pertenece el mosaico hispano romano de la Bética, el pavimento de los Amores de Júpiter, hallado en Itálica (Sevilla), que se conserva en la colección de la Condesa de Lebrija, y se data en la segunda mitad del siglo II ${ }^{57}$ (Fig.25). La superficie del mosaico, que forma prácticamente un cuadrado, ostenta un esquema compositivo de cuadriculado de círculos grandes y pequeños tangentes, nueve grandes y ocho pequeños, en lacería de trenza de dos cabos, que determinan cuatro octógonos irregulares cóncavos. El medallón central se ha decorado con un busto masculino tocando la siringa, identificado probablemente con Argos y también con Pan, Apolo o Polifemo, mientras que las Estaciones ocupan los cuatro medallones de los ángulos. Los cuatro círculos restantes, situados en el centro de los lados, y los octógonos centrales están ocupados por el ciclo de los amores de Júpiter: Leda y el cisne, Ganímedes dando de beber al águila de Zeus, Dánae recibiendo la Iluvia de oro, lo con la media luna marcada en su vientre, Europa y el toro, Arcas y Calisto metamorfeado en osa, Antiope perseguida por el sátiro, el río Asopos, padre de Egina ${ }^{58}$. La escena de Leda ocupa el círculo central de la parte inferior del pavimento y en ella la joven aparece medio recostada hacia la derecha sobre el manto, que le cubre la espalda y lo enrolla en el brazo izquierdo, dejando al descubierto el resto del cuerpo; con la mano derecha coge al císne que se aproxima hacia ella.

El tipo de Itálica se repite, en el mosaico de Ancône, de época antonina, que se conserva en el Museo de Pesaro ${ }^{59}$, con la particularidad de que aquí la escena se desarrolla en un ambiente terrestre y acuático más propio del primer momento. Leda figura medio recostada hacia la derecha

paganos y cristianos, cf. J. LAUZZERE, «Le mythe de Leda dans l'art copte", Bull. de l'Association des Amis de I'Art Copte 2, 1936, 38-46; R. HuYGUE, El arte y el hombre, Barcelona 1966; H. TORP, "Leda Christiana. The problem of the interpretation of coptic sculture with mythological motifs", AAAH 4, 1969, 101-112.

57 A. Blanco, Mosaicos romanos de Mérida, CMRE II, Madrid 1978, 25-26, n. ${ }^{\circ} 1$, láms. 1 y 3b; O. WATTEL-DE-CROIZANT, "La représentation des amours de Júpiter sur une mosaíque d'ltalica", Annales de Bretagne et des Pays de l'Ouest 81, 2, 1974, 285-299.

58 «López Monteagudo, M.P. San NIcolás Pedraz, op. cit. (nota 10), 391-394, fig. 8.

59 P. MARCONI, "ll mosalco pesare di Leda", Bolletino d'Arte XXVI, 1933, 445-454; G. CANUTI, op. cit. (n. ${ }^{\circ}$ 23), 86-87, n. ${ }^{\circ}$ 19; L. MERCANDO, «I mosaici romani», en VV.AA., Pesaro nell'antichità. Storia e monumenti, Pesaro 1995, 167-169, n. ${ }^{\circ}$ láms. 50-53b, y portada. 


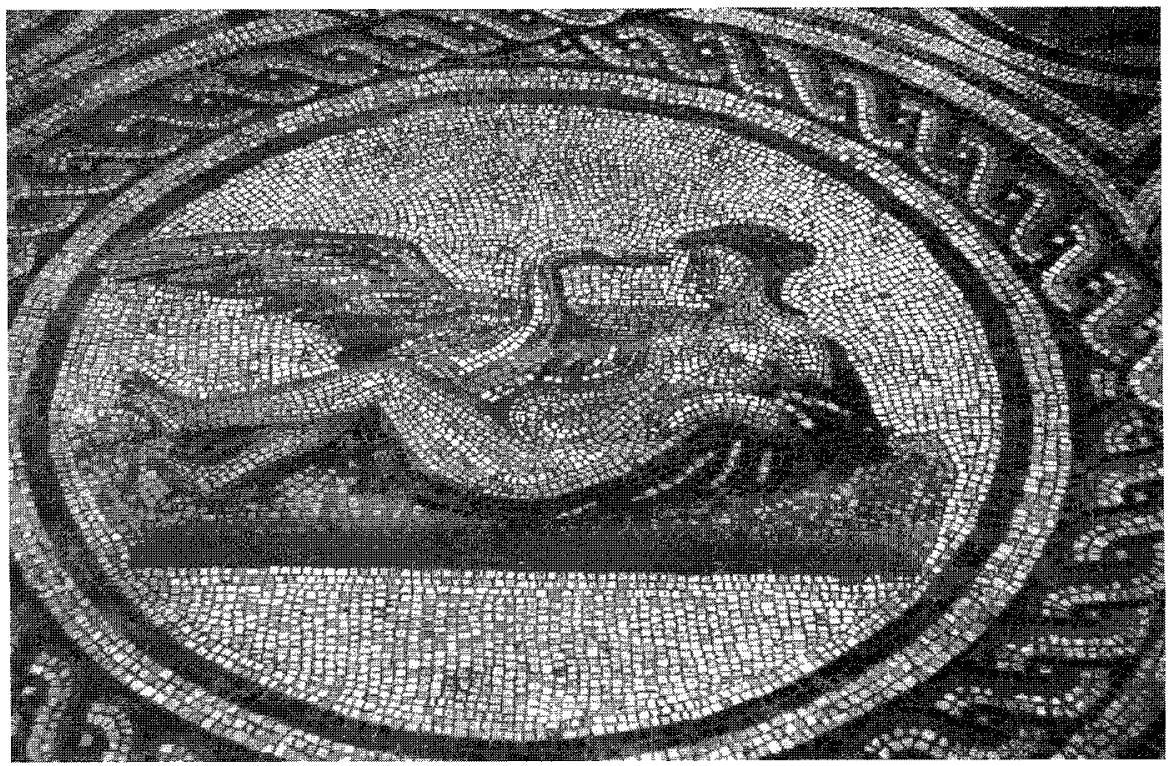

Fig. 25. Itálica. Mosaico de los Amores de Júpiter. Casa de la Condesa de Lebrija. Foto G. López Monteagudo.

sobre un manto que solo le cubre su pierna izquierda; con la mano del mismo lado coge el cuello del cisne, a la vez que éste la enlaza con su ala y aproxima su pico a la boca de la doncella. A la derecha aparece una baja columna (Fig. 26), posiblemente con la misma simbología que la del mosaico de Nîmes.

El mismo grupo de Leda y el cisne lo encontramos en el mosaico de Orthasia (Turquía), probablemente procedente de una villa, del siglo II-III ${ }^{60}$. Este mosaico, de forma rectangular, está bordeado por una franja en la que está representada varios animales corriendo, un jinete, una barca, cocodrilo, tortuga, figuras mitológicas, gladiadores, Heracles en la laguna Stymphalia. El emblema central está dividido en cuatro paneles en los que figuran, de izquierda a derecha, Leda y el cisne, restos de una posible cuadriga, Pan y Ninfa, Tritón y Amphitrite. Leda aparece como en Itálica y Ancône pero en posición invertida, y al igual que en éste último se ha representado la columna, pero aquí detrás del grupo y en un fondo de árboles. Sin embargo la particularidad más

60 E. YENER, F. ÖLMER, "Orthasia Mozaik Kurtarma Kazisi ve Mozaik Kaldiri (1995)», VII Müze KurtarmaKazilari Semineri, 1997, 276, figs. 3 y 5. 


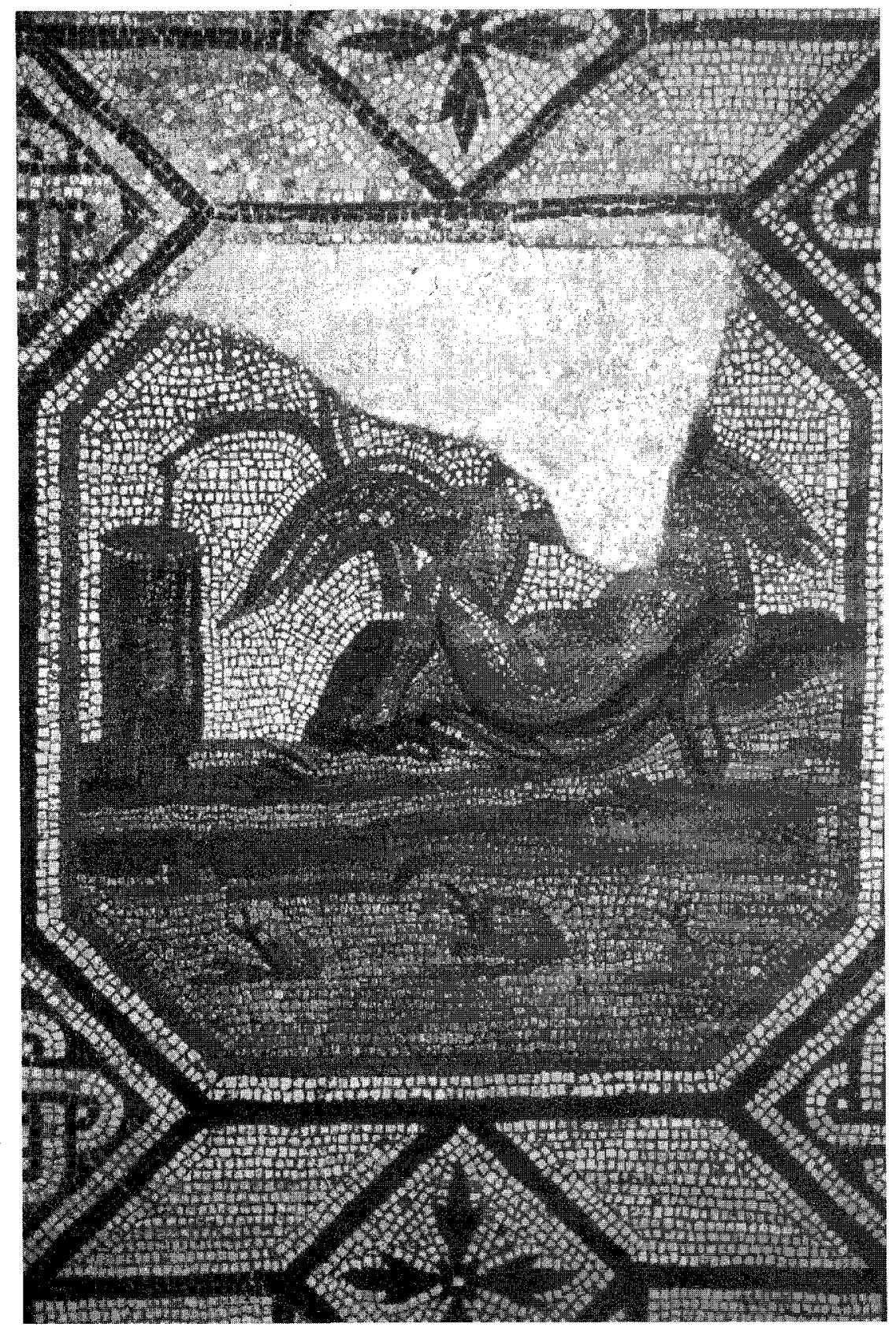

Fig. 26. Mosaico de Ancône. Museo de Pesaro. Cortesía de M.L. Neira. 


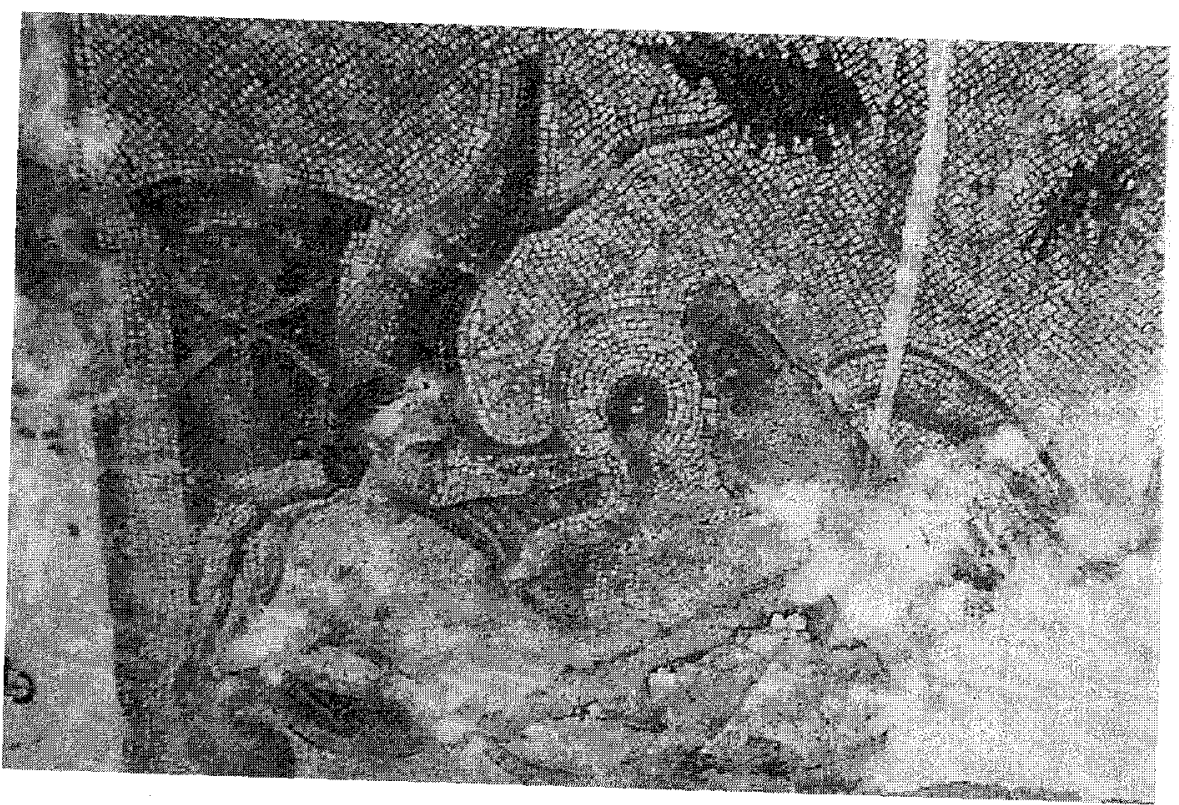

Fig. 27. Mosaico de Orthasia, Turquía.

sobresaliente de este mosaico es la marcada flexión del cuello, rozando con el pico el pecho de la joven como iniciando la acción de buscar los labios para besarla, pudiendo decirse que esta escena sería la pri-
mera secuencia del grupo.

La segunda variante del tipo de Leda recostada se documenta en dos pavimentos. En el mosaico del Djem, la antigua Thysdrus, datado a finales de época severiana ${ }^{61}$. En uno de los medallones Leda se ha figurado, como en Orthasia, desnuda y medio recostada sobre el manto que enrolla en el brazo derecho, mientras con la mano derecha atrae hacia ella al cisne; sin embargo aquí, el animal, aunque también tiene flexionado el cuello, posa su pico sobre los labios de la joven y ella lleva en la frente una cinta a modo de diadema (Fig.28).

En otro mosaico norteafricano hallado en Aumale (Argelia), hoy perdido, aparecia la misma escena de Leda y el cisne ${ }^{62}$, pero a diferencia con los mosaicos anteriores del mismo grupo, Leda aparece nimbada, posiblemente aludiendo a su divinización a través del hiéro gamos.

\footnotetext{
51 L. Foucher, Découvertes archéologiques 'Thysdrus en 1961, 1961, 23, lám. 25, c.

62 F.G. PACHTERE, op. cit. (nota 4), n. ${ }^{\circ} 351$; DUNBABIN, op. cit. (nota 4), 248.
} 


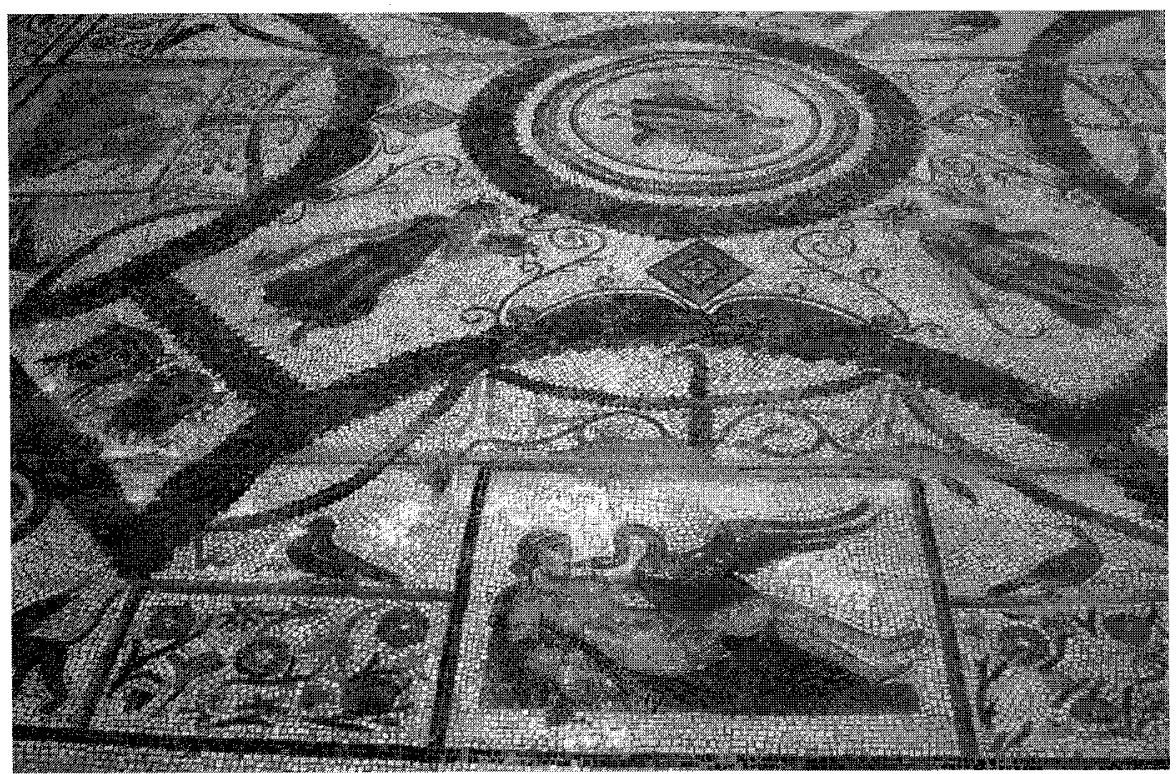

Fig. 28. Mosaico de Thysdrus. Foto G. López Monteagudo.

La tercera fase del mito o la consecuencia de su unión con Júpiter se figuró en un interesante pavimento descubierto en la residencia imperial de Tréveris, datado en la segunda mitad del siglo IV ${ }^{63}$. En la escena figura un altar con el huevo que contiene tres niños: Cástor, Pólux y Helena, y encima de ellos en forma de águila, Júpiter, posada sobre una columna de estilo dórico, que para algunos autores sería un líquido que derrama el águila sobre el huevo, como figura en los relieves (infra), en relación con algún rito desconocido. A la izquierda aparece Agamenón y a la derecha Leda; todos los personajes están identificados por su nombre. La princesa está vista de tres cuartos, mirando hacia su derecha, adornada con collar, pendientes y brazaletes como en el citado mosaico de Nea Paphos; lleva manto por detrás de la espalda que alza con la mano izquierda y recoge con la derecha en la parte delantera, intentando cubrir su cuerpo desnudo con gesto pudoroso (Fig. 29).

El tipo iconográfico de Leda levantando su mano es propio, como ya se ha señalado, de las representaciones que evocan la primera fase del

63 J. Moreau, Das Trierer Kornmasktmosaik. Monumenta Artis Romanae, II, Colonia 1960, 17, lám. 22; J.-J. HATT, «Une nouvelle interprétation de la mosaïque du Kornmarkt», BullSAntF, $1985,37-45$. 


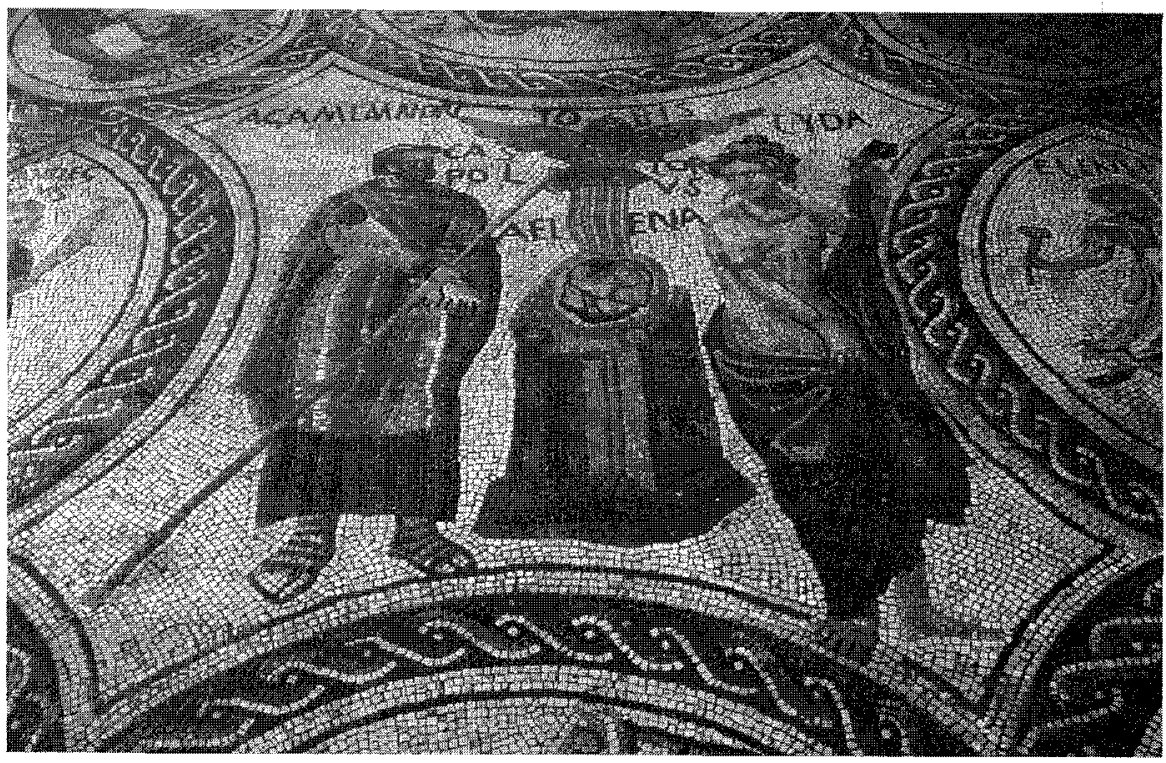

Fig. 29. Mosaico de Tréveris. Foto G. López Monteagudo.

mito, en las cuales siguiendo la versión de Eurípides, la joven protege al cisne amenazado por el águila. Sin embargo, aquí la escena representada es más compleja y se le ha dado un sentido cósmico y escatológico en relación con los cultos galo-romanos ${ }^{64}$, e ilustra el nacimiento de los tres hermanos nacidos de un huevo como relatan Servio (Aen. 3, 328) y Horacio (Ars 147). En este mosaico la presencia de Agamenón junto a los Dióscuros, en lugar de Tindareo, se debe probablemente por su calidad de haber sido iniciado en los misterios de Samotracia (Schol. Apol. Rhod. I 916-918; Diod. V 48-49) ${ }^{65}$. A pesar que en la versión más conocida del mito, Leda aparece como la madre de los trillizos, en otra tradición ella es solamente la nodriza humana, mientras que Némesis es la madre. J. Moreau estima que aquí estamos en presencia de una versión ilustrada del mito y que la deidad principal debía ser Némesis, cuyo culto era muy popular en la Antigüedad Tardía; según K.M.D. Dunbabin el huevo tendría connotaciones de renacimiento ${ }^{66}$.

64 Religio romana. Wege zu den Göttern im antiken Trier, Trèves, Selbstverlag des Rheinischen Landesmuseums Trier, 1996, 244, fig. 55.

65 J. Bousquet, "Callmaque Hêrodote et le trône de l'Hermès de Samothrace», Mélanges d'Archeologie et d'Histoire offerts à Ch. Picard, Paris 1949, 105-131.

66 K.M.D. DunBaBIN, Mosaics of the Greek and Roman World, Cambridge 1999, 82-85, fig. 85. 
Los paralelos más próximos para el huevo con los trillizos junto a Leda se documentan en dos sarcófagos, uno procedente de Aix-en-Provence junto a la primera secuencia del mito (supra), y el otro del hipogeo de Aguazzano (Roma), de época de Vespasiano, conservado en el Museo Nazionale de Roma (Fig. 30), y en un bronce también procedente de Roma, fechado en el siglo IV; en todos ellos a diferencia con el ejemplar musivo de Tréveris, el huevo aparece roto y los niños dentro de él ${ }^{67}$.

En general, tras el análisis de estos pavimentos, puede decirse que, entre las escenas dedicadas a la mitología, la musivaria romana ha proporcionado un gran número de ejemplares de Leda y el cisne, comparable, dentro de su género "Amores de Júpiter», con Europa y el toro, y Ganimedes y el águila. En ellos se aprecian distintas series que completan el mito, con una amplia cronología que abarca desde el siglo II al VI. Los episodios más representados fueron el del encuentro de Leda y el cisne, que se figura con distintas variantes, y el de la unión amorosa en su tipo iconográfico de Leda recostada, mientras que la consecuencia de la unión, Leda y el huevo, solamente se figuró en el pavimento de Tréveris.

En la musivaria romana, al igual que en la mayoría de las representaciones artísticas del mito, no figura el águila persiguiendo al cisne - solamente se muestra en la pintura de la Casa del Citarista y en la copa etrusca de Clusium-, y lo que es más notable no está representado el tipo escultórico de Timoteo, en el que Leda aprieta contra ella y con una mano levanta su manto para protegerlo del águila. Sin embargo el conjunto musivo ofrece unas particularidades tanto en la elección de los episodios como en el tratamiento iconográfico, pudiendo decirse que cada uno de los pavimentos constituyen secuencias diferentes del mito, que a veces, como ocurre en los mosaicos de Suasa y Ecija entre otros, son consecutivas. En estos dos mosaicos es notable el tipo artístico de Leda en pie y de espaldas en el mismo momento de ser poseída por el cisne que solo se documenta, hasta el momento, en la musivaria romana y que solo puede ponerse en relación con la escena del pavimento chipriota de Palaepaphos (Kouklia), que representa el momento de la huida.

Aunque una de las peculiaridades más notables del tratamiento de la aventura amorosa de Leda y el cisne en la musivaria romana es su carencia narrativa, no por ello excluye la ausencia del relato mítico, sino que a través de unas reducidas imágenes - Eurotas, Lacedemonia, compañe-

67 LIMC, III, Dioskouroi/ Castores, 1986, n. ${ }^{\circ} 146$ y $146 a ;$ IV, Eurotas, 1988, $\mathrm{n} .^{\circ} 6$; IV Helena, $1988,{ }^{\circ} 11$ y $14 ; \mathrm{VI}$, Leda, 1992, n. ${ }^{\circ} 139,140-141$. 


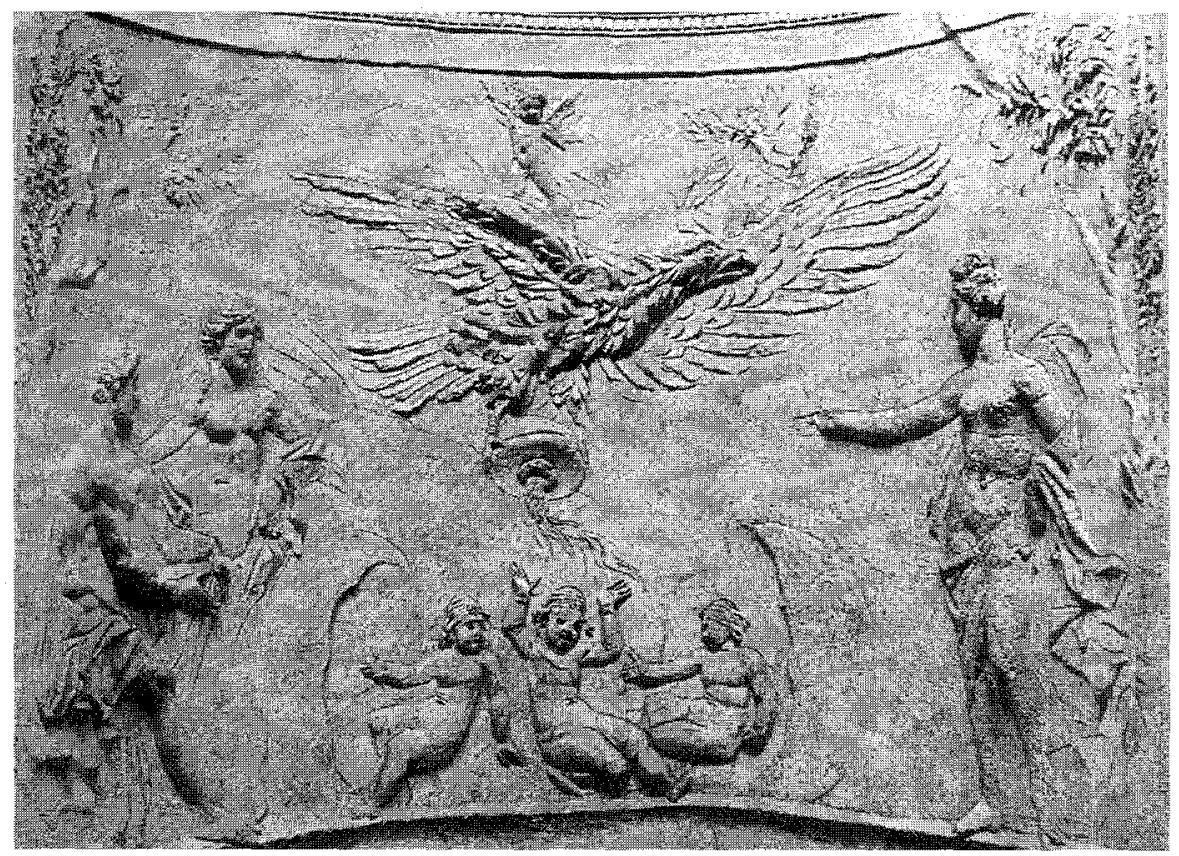

Fig. 30. Relieve del hipogeo de Aguzzano. Roma. Museo Nacional de Roma.

ras de Leda, Eros, Júpiter o su rayo, Cástor- se nos cuenta la totalidad del mito. La representación de Complutum constiyuye un unicum en el conjunto, no porque se identifican los personajes a través de sus nombres como ocurre con los mosaicos de Nea Paphos, Orthasia y Tréveris, sino que la inscripción parece indicar el mismo momento de la unión de la pareja sin estar representada, lo que constituye un «ejemplo abreviado» en donde la imagen implica otra lectura que la simplemente visual por contener en sí varios episodios o etapas del relato mítico.

En cuanto al contenido simbóilico de estas representaciones no solo debemos verlo como una simple aventura amorosa, sino como una alegoría de la fecundidad a través de la hierogamia de la pareja. Por lo tanto, la presencia del tema constituye, en contextos domésticos, una expresión de felicidad y bienestar eterno para los habitantes de la casa. 